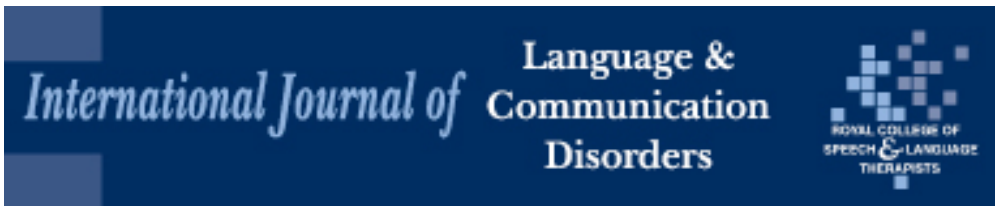

\title{
Speech, language and swallowing impairments in functional neurological disorder: A scoping review.
}

\begin{tabular}{|r|l|}
\hline Journal: & International Journal of Language \& Communication Disorders \\
\hline Manuscript ID & TLCD-2018-0139.R1 \\
\hline Wiley - Manuscript type: & Review \\
\hline Keywords: & $\begin{array}{l}\text { functional neurological disorder, dysarthria, dysphagia, dysphasia, } \\
\text { psychogenic, speech }\end{array}$ \\
\hline
\end{tabular}

\section{SCHOLARONE \\ Manuscripts}


Speech, language and swallowing impairments in FND

Speech, language and swallowing impairments in functional neurological disorder:

\section{A scoping review.}

Running head: Speech, language and swallowing impairments in FND

Key words: functional neurological disorder, psychogenic, speech, dysarthria, dysphasia, dysphagia 
Speech, language and swallowing impairments in FND

\section{Declaration of Interest}

No conflicts of interest have been identified. The authors alone are responsible for the content of this paper.

\section{Acknowledgements}

The author was supported in the writing of this review by an NIHR-funded Clinical Academic Internship Programme delivered by Birmingham Health Partners. 
Speech, language and swallowing impairments in FND

\section{Structured Abstract:}

Background: Functional neurological disorder (FND) is common across healthcare settings. The Diagnostic and Statistical Manual of Mental Disorders states that speech and swallowing symptoms can be present in FND. Despite this, there is a dearth of guidelines for speech and language therapists (SLTs) for this client group.

Aim: To address the following question in order to identify gaps for further research: What is known about speech, language and swallowing symptoms in patients with FND?

Methods: A scoping review was conducted. Six healthcare databases were searched for relevant literature: CINAHL PLUS, MEDLINE, ProQuest Nursing and Allied Health Professionals, Science Citation Index, Scopus and PsychINFO.

Main Contribution: 63 papers were included in the final review which ranged from 1953 to 2018. Case studies were the most frequent research method $(n=23,37 \%)$. "Psychogenic" was the term used most frequently $(n=24,38 \%)$ followed by "functional" $(n=21,33 \%)$. Speech symptoms were reported most frequently $(n=41,65 \%)$, followed by language impairments $(n=35,56 \%)$ and then dysphagia $(n=13,21 \%)$. Only 11 publications comment on the involvement of SLTs. Eight papers report direct speech and language therapy input however none studied the effectiveness of speech and language therapy.

Conclusion: Speech, language and swallowing symptoms do occur in patients with FND yet is a highly under-researched area. Further research is required to create a set of positive diagnostic criteria, gather accurate data on numbers of patients with FND and speech, language or swallowing symptoms and to evaluate the effectiveness of direct speech and language therapy involvement. 
Speech, language and swallowing impairments in FND

\section{What this paper adds:}

What is already known on the subject

Functional neurological disorders (FND) are not included in the Royal College of Speech and Language Therapist's Clinical Guidelines (2005). Therefore a scoping review was conducted in order to discover what literature currently exists on the topic of FND and speech and language therapy.

\section{What this paper adds to existing knowledge}

This scoping review highlights that functional speech, language and swallowing symptoms do exist in patients with FND, with dysarthria listed as the second most common symptom observed in patients with functional stroke mimics. This area is, however, largely underresearched and this paper highlights multiple avenues for further research.

\section{What are the potential or actual clinical implications of this work?}

Further research and consensus guidelines are required in order to agree on terminology to be used consistently within clinical practice and to develop a set of positive diagnostic criteria. Focussed descriptive research is required in order to accurately report on numbers of patients with FND with speech, language or swallowing symptoms. Empirical research is also needed in order to assess the effectiveness of direct speech and language therapy involvement in order to improve outcomes for patients with FND in the future. 
Speech, language and swallowing impairments in FND

\section{Introduction}

Functional neurological disorder (FND) is common across healthcare settings. It has been shown to be the second most common diagnosis in neurology clinics (Stone et al. 2010a) and exist in $7 \%$ of patients on a neurology ward (Parry et al. 2006). Functional stroke mimics also comprise up to $2 \%$ of stroke admissions (Vroomen et al. 2008) and represent $7.4 \%$ of stroke mimics (Gibson \& Whiteley 2013). FND includes a wide variety of motor or sensory symptoms which would usually be under a person's voluntary control, such as walking, talking or swallowing. In FND these symptoms occur in a way which is incompatible with known neurological conditions and which have a clinically significant impact on a person's functioning (American Psychiatric Association 2013). Historically, a psychological stressor was required to make a diagnosis of FND. This requirement was reclassified as optional, however, for the fifth edition of the Diagnostic and Statistical Manual of Mental Disorders (DSM-5) (American Psychiatric Association 2013). This reflects a shift in nomenclature from terms such as "hysteria" and "psychogenic" which assume a psychological aetiology, to terms such as "functional" which are broader and fit with a biopsychosocial model of aetiology (Ganos et al. 2014a; Demartini et al. 2016).

Diagnosis of FND should be made by a neurologist following detailed assessment from an interdisciplinary team. It should not be a diagnosis simply of exclusion (Edwards \& Bhatia 2012). Neurologists are encouraged to approach history taking in a structured format, to give the patients a diagnostic label and to show patients their physical signs (Carson et al. 2012). Management of FND begins with the explanation of the disorder itself (Stone et al. 2016a). Other possible treatment options include: pharmacotherapy, physical therapy, cognitive behavioural therapy and hypnosis. An interdisciplinary approach is often recommended, 
Speech, language and swallowing impairments in FND

although more robust research is required to assess the effectiveness of treatments for FND (Stone et al. 2005; Edwards \& Bhatia 2012).

Speech and language therapists (SLTs) have a role in contributing to the assessment and diagnosis of neurological conditions through the specialist assessment of motor speech disorders, language impairments, swallowing disorders, voice difficulties and cognitive communication disorders. The DSM-5 states that both speech and swallowing symptoms can be present in FND. SLTs, therefore, have the specialist skills to identify when speech, language, swallowing, voice or cognitive communication symptoms occur in a way incompatible with known neurological conditions and thus contribute to the diagnosis of FND. Despite this, there is no mention of FND in the Royal College of Speech and Language Therapists' (RCSLT) Clinical Guidelines (2005). Although “psychogenic” is listed as a possible aetiology of dysphagia, no detailed guidelines currently exist on the management of this client group (RCSLT 2018).

Despite there being a lack of guidelines specific to FND, SLTs are currently involved in the management of some functional conditions. For example, functional dysphonia and globus pharyngeus are diagnoses which are embedded into routine clinical practice (RCSLT 2005; Baker 2016; Baumann and Katz 2016). Awareness of functional speech conditions, such as stuttering or foreign accent syndrome, are also increasing in recent years; however these are "frequently ignored and often not emphasized" (Duffy 2016: 380). Anecdotally, however, SLTs encounter functional symptoms other than those listed above, such as aphasia, dysgraphia or oropharyngeal dysphagia. The purpose of this review, therefore, was to address the question: What is known about speech, language and swallowing symptoms in patients with FND? A scoping review was conducted with the aim of identifying gaps for further research. 
Speech, language and swallowing impairments in FND

\section{Method}

This scoping review was based on the methodological framework proposed by Arksey and O’Malley (2005) and further developed by Levac et al. (2010) and Peters et al. (2015). The purpose of a scoping review is to "examine the extent, range and nature of research activity" (Arksey \& O’Malley 2005:21). It aims to cover breadth of knowledge on a complex topic as opposed to depth of knowledge in a specific area. For this reason, assessment of quality of included studies is not a standard component in scoping reviews. They are useful for topics with emerging evidence in order to map what is currently known on a topic as they allow the inclusion of all types of published work. Scoping reviews are adept at identifying gaps for further research and as such are increasingly being used in health research (Pham et al. 2014).

An initial Internet search of our topic highlighted a dearth of research. We therefore selected the scoping review method as it allowed the inclusion of a wide range of study designs in order to address our broad research question. A five stage methodological framework was used: 1) identifying the research question, 2) identifying relevant studies, 3) study selection, 4) charting the data and 5) collating, summarising and reporting the results (Arksey \& O’Malley 2005).

\section{Identifying the research question}

Our initial research question included the parameter of inpatient settings only. This yielded minimal results, however, and was not effective in providing a wide coverage of the topic area. Therefore, the research question was revised to include all settings and to be intentionally broad in order to generate an expansive coverage of potential studies (Levac et al. 2010). We focussed on the question: What is known about speech, language and swallowing symptoms in FND? A broad spectrum of symptoms was included in the original 
Speech, language and swallowing impairments in FND

search terms (please see Appendix I). In line with the scoping review methodology, the parameters of what symptoms to include and definition of FND were later refined following familiarity with the literature and are outlined below.

\section{Identifying relevant studies}

An initial Internet search and hand searching of journals was completed in order to identify key terms for our question. The advice of a health sciences librarian was sought in order to identify further key search terms and also relevant databases to search. 12 different search terms for FND were used to search the databases (see Appendix I).

The original search was conducted in January 2017 and the following electronic databases were searched using Boolean terms: Cumulative Index to Nursing and Allied Health Literature (CINAHL PLUS), MEDLINE, ProQuest Nursing and Allied Health Professionals and Science Citation Index. The Boolean/Phrase search for CINAHL PLUS database returned no results however 2,308 results were returned using their Smart Text Searching and these were screened for relevance. Reference lists were searched for further potential studies as well as professional networks and Google Scholar. In order to capture recently published research, the search on the above databases was re-run in September 2018. Two further databases, Scopus and PsychINFO, were also searched in order to gather further studies to answer our question (see Figure 1).

Only studies in English language and focussing on adults were included. No date limits were set as it was anticipated there would be limited research on the topic and our aim was to be as broad as possible. Our scoping review included quantitative and qualitative studies as well as grey literature. 
Speech, language and swallowing impairments in FND

\section{Study selection}

Criteria for study selection were iteratively revised throughout our process, in line with the scoping review method and are outlined below (Levac et al. 2010). As stated, our initial search included inpatient settings only so a further search to include all settings was completed (see Figure 1). In January 2017 the lead reviewer initially screened 4,405 search results and removed irrelevant articles. The Smart Text Search results from CINAHL PLUS were screened until a point of saturation and irrelevance was reached (466 articles). Two reviewers then screened 186 titles and abstracts for further review and 67 full texts were read and considered for inclusion by both reviewers. 


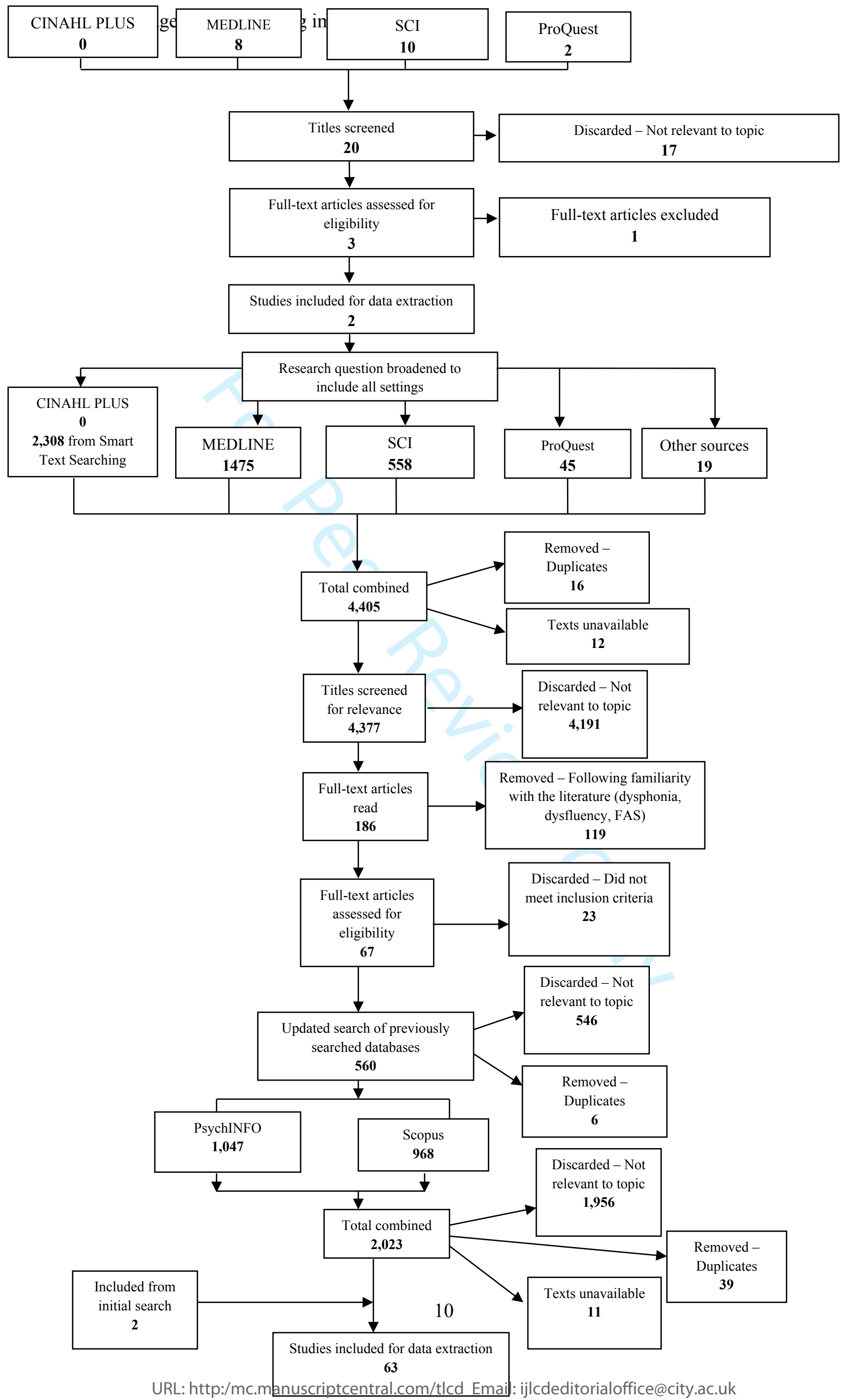

Figure 1: Flow chart of searching strategy. SCI=Science Citation Index; FAS=foreign accent syndrome 
Speech, language and swallowing impairments in FND

Following familiarity with the literature, the following symptoms were excluded from our search: dysphonia, globus pharyngeus and dysfluency. This is because these symptoms in relation to psychogenicity are well established among SLTs. Foreign accent syndrome was also excluded from this review. This is because foreign accent syndrome has an emerging literature with regards to both organic and functional origins. It is a diagnostic label which many will recognise as a term, even if not fully understood. The aim of this review was to focus on symptoms which are not as universally recognised with regards to FND.

Oesophageal dysphagia was also excluded. Although SLTs can, and often are, involved in the assessment of patients with oesophageal dysphagia, it was not the focus of this review. Limits were set in order to refine the question into a manageable piece of work.

We only included studies which adhered to the DSM-5 criteria of FND (American Psychiatric Association 2013). This means that a psychological stressor was not necessary for diagnosis of FND, as was suggested in previous versions of the DSM. The DSM-5 also specifies factitious disorder and malingering as differential diagnoses to FND. Our initial database search included terms such as "Munchausen" and "malingering". Due to the fact that terminology and diagnostic criteria have evolved over time we used broad search terms initially in order to capture all possible articles for inclusion. If, when reading the full text, a definitive statement of conscious intent to feign symptoms was given then articles were excluded. Studies involving litigation were excluded due to the high possibility of malingering.

When the search was re-run in September 2018 on the four databases, a further 560 papers were found. Eight of these met the above inclusion criteria, as agreed by two reviewers. A further 2,015 papers were found from Scopus and PsychINFO databases and nine met the inclusion criteria. If disagreement occurred between two reviewers with regards to exclusion 
Speech, language and swallowing impairments in FND

criteria then a third reviewer appraised the article and a consensus was reached. A total of 63 articles were included in the final data extraction.

\section{Charting the data}

A data extraction form was created and data from the most recent five studies were independently charted onto Microsoft Excel spreadsheet by two reviewers in order to check for consistency. The reviewers discussed whether approaches were consistent and whether the data being extracted answered the research question. Following revisions, the final data charted were: author(s), year of publication, country of study, aims, research method, setting, terminology of diagnoses, treatment approach, type of speech and language symptoms and SLT involvement (see supporting information for data extraction chart). Where country of study was not explicitly stated, the country of lead author was extracted.

\section{Results}

Distribution of articles by year

Texts included in the final analysis ranged from 1953 to 2018. The largest proportion of articles were published in $2012(\mathrm{n}=8,13 \%)$, followed by $2018(\mathrm{n}=7,11 \%) .20$ texts $(32 \%)$ were published in the 2000 s whereas 36 texts $(57 \%)$ have been published thus far this decade. This indicates a trend for increasing interest in this topic area given that over half of included articles were produced in the last eight years.

\section{Distribution of articles by country of authorship}

A total of 20 countries of publication were included in the final analysis (see supplementary material for table of countries). The majority of texts were published in the United States of America (USA) ( $n=25,40 \%)$ followed by the United Kingdom (UK) $(n=12,19 \%)$. When 
Speech, language and swallowing impairments in FND

grouped into continents, the Americas produced 29 texts $(46 \%)$, followed by Europe ( $n=28$, 44\%), Asia $(n=3,5 \%)$, the Middle East $(n=2,3 \%)$, and Australasia $(n=1,2 \%)$. Two of the papers included in the review involved two countries: France and Serbia (Chen et al. 2011); USA and Spain (Cubo et al. 2005).

\section{Research methods}

A total of 13 different methods were included, with some papers involving more than one method (see Table 1). Case studies were the most frequent method used ( $n=23,37 \%)$ followed by retrospective analysis of data $(n=13,21 \%)$. One randomised controlled trial was included (Moene et al. 2002). The focus of this trial, however, was the effectiveness of hypnosis in FND and did not focus on speech and language therapy involvement but was included in this review because $13 \%$ of their sample reported "speech disturbance". Only 18 papers $(29 \%)$ included speech, language or swallowing symptoms in their aims. The other citations mentioned relevant symptoms in the main body of the text and detail was often lacking. 
Speech, language and swallowing impairments in FND

\begin{tabular}{ll}
\hline Research method & Number of articles \\
\hline Case report(s) & 23 \\
Case control study & 2 \\
Cohort study & 1 \\
Double dissociation experiment & 1 \\
Interview & 3 \\
Opinion piece & 1 \\
Prospective analysis & 5 \\
Questionnaires & 4 \\
Randomised controlled trial & 1 \\
Rating scale development & 2 \\
Report & 1 \\
Retrospective analysis & 13 \\
Review & 8 \\
\hline
\end{tabular}

Table 1: Distribution of number of articles by research method

Terminology

A total of ten different terms were used to describe FND within the search results (see Table 2). These terms were used 79 times within the 63 included texts as 13 publications used more than one term within their papers. "Psychogenic" was the term used most frequently $(n=24$, $38 \%)$ followed by "functional" $(\mathrm{n}=21,33 \%)$ and then "conversion" $(\mathrm{n}=19,30 \%)$. The term "functional" was used more than other terms in the most recent decade. Ten of the 13 papers which used more than one diagnostic label were produced in the 2010s. 
Speech, language and swallowing impairments in FND

\begin{tabular}{|c|c|c|c|c|c|c|c|}
\hline Diagnostic term & $1950 \mathrm{~s}$ & $1960 \mathrm{~s}$ & $1980 \mathrm{~s}$ & $1990 \mathrm{~s}$ & $2000 \mathrm{~s}$ & $2010 \mathrm{~s}$ & Total \\
\hline Psychogenic & 1 & & & 3 & 8 & 12 & 24 \\
\hline Conversion & & 1 & & 1 & 9 & 8 & 19 \\
\hline Functional & & 1 & & & 2 & 18 & 21 \\
\hline Somatoform & & & & & & 3 & 3 \\
\hline Non-organic & & & & & & 2 & 2 \\
\hline Non-neurogenic & & & & & & 1 & 1 \\
\hline Ganser's & & & & & 1 & 1 & 2 \\
\hline Dissociative & & & & & & 2 & 2 \\
\hline Hysteria & 1 & & 1 & & & 1 & 3 \\
\hline Medically unexplained & & & & & 1 & 1 & 2 \\
\hline Total & 2 & 2 & 1 & 4 & 21 & 49 & 79 \\
\hline
\end{tabular}

Table 2: Distribution of articles by terminology of diagnoses and year

Functional stroke mimics

Four articles were included in the final results which describe functional stroke mimics and include details of speech, language or swallowing symptoms. The number of functional stroke mimics admitted to stroke units ranged from $0.4 \%-8.4 \%$ (Chen et al. 2011; Artto et al. 2012; Guillan et al. 2012; Gargalas et al. 2017). A total of 111 patients with functional stroke mimics were described across the four articles. Dysarthria was reported in $20 \%$ $(\mathrm{n}=22)$ of these patients and dysphasia in $15 \%(\mathrm{n}=17)$. Gargalas et al. (2017) report that dysarthria was the second commonest presentation for functional stroke mimics on admission to a hyper acute stroke unit. This paper also reports that some patients presented with "difficulties swallowing" under "miscellaneous presentations" among the functional stroke mimics. However, specific numbers of patients presenting with dysphagia in this population were not reported. 
Speech, language and swallowing impairments in FND

\section{Setting}

A total of 20 different settings were reported in the publications with some papers including more than one setting. 30 papers (48\%) reported involvement in an inpatient setting and 22 papers (35\%) reported involvement in an outpatient setting (see Table 3). Movement disorders clinic was the most frequently reported setting $(n=9,14 \%)$. The setting was either not stated or not applicable in 14 papers $(22 \%)$ and five papers $(8 \%)$ were conducted in a research centre.

\begin{tabular}{llll}
\hline Inpatient setting & \multicolumn{2}{l}{ Outpatient setting } & \\
\hline Emergency room & 5 & Brain injury clinic & 1 \\
Epilepsy monitoring unit & 1 & Medical centre & 1 \\
Inpatient (speciality not specified) & 6 & Memory clinic & 1 \\
Inpatient rehabilitation ward & 3 & Movement disorders clinic & 9 \\
Neurology ward & 4 & Neurobehavioural clinic & 2 \\
Psychiatric ward & 3 & Neurology clinic & 4 \\
Stroke unit & 4 & Otology and laryngology department & 1 \\
Surgery & 3 & Outpatient (speciality not specified) & 1 \\
Tertiary care centre & 1 & Psychiatric clinic & 1 \\
& & Psychology clinic & 1 \\
Total & 30 & Total & 22 \\
\hline
\end{tabular}

Table 3: Distribution of number of articles by setting

Speech, language and swallowing symptoms

A total of 26 papers included more than one relevant symptom for this review. Speech symptoms were reported in 41 of the 63 papers (65\%). Publications charted under speech symptoms included articles which specifically stated dysarthria but also if they used terms such as "functional speech disorder" and the details of symptoms were not specified. Language impairments were reported in 35 papers (56\%) and were broken down into the 
Speech, language and swallowing impairments in FND

following symptoms in order of frequency: aphasia $(n=22,35 \%)$, dysgraphia $(n=5,8 \%)$, mutism $(n=5,8 \%)$ and alexia $(n=4,6 \%)$. Dysphagia was reported in 13 of the 63 publications (21\%). 20 papers included specific numbers of participants who presented with speech, language or swallowing symptoms and FND. These ranged from 2\% to 97\% (see Table 4).

\begin{tabular}{|c|c|c|c|}
\hline References & $\begin{array}{l}\text { Number of } \\
\text { patients }\end{array}$ & $\begin{array}{l}\text { Number of patients with } \\
\text { speech, language or } \\
\text { swallowing symptoms (\%) }\end{array}$ & $\begin{array}{l}\text { Clinical presentation of speech, } \\
\text { language or swallowing } \\
\text { symptoms }\end{array}$ \\
\hline Akyüz et al. (2017) & 60 & $58(97)$ & Aphasia \\
\hline $\begin{array}{l}\text { Baizabal-Carvallo and } \\
\text { Jankovic (2015) }\end{array}$ & 182 & $4(2)$ & Speech arrests \\
\hline $\begin{array}{l}\text { Baizabal-Carvallo and } \\
\text { Jankovic (2017) }\end{array}$ & 9 & $4(44)$ & Abnormal speech \\
\hline Cantello et al. (2001) & 21 & $2(10)$ & $\begin{array}{l}\text { Motor aphasia, dysarthria, } \\
\text { global aphasia }\end{array}$ \\
\hline Cubo et al. (2005) & $\begin{array}{l}88 \text { (USA) } \\
48 \text { (Spain) }\end{array}$ & $\begin{array}{l}16(18) \\
11(23)\end{array}$ & Speech symptoms \\
\hline $\begin{array}{l}\text { Czarnecki et al. } \\
\text { (2012) }\end{array}$ & 60 & $7(12)$ & Speech disorder \\
\hline Epstein et al. (2016) & 36 & $6(17)$ & Functional speech \\
\hline Ertan et al. (2009) & 49 & $4(8)$ & Bizarre speech \\
\hline Factor et al. (1995) & 28 & $1(4)$ & Slow halting voice \\
\hline Fasano et al. (2012) & 46 & $18(39)$ & $\begin{array}{l}\text { Slurred speech, burst of verbal } \\
\text { gibberish }\end{array}$ \\
\hline Ganos et al. (2014b) & 26 & $6(23)$ & Speech disturbances \\
\hline Hinson et al. (2005) & 88 & $25(28)$ & Speech dysfunction \\
\hline Jacob et al. (2018) & 32 & $18(56)$ & Affected speech \\
\hline Jokel and Wolf (2017) & 10 & $2(20)$ & $\begin{array}{l}\text { Dysgraphia, alexia, naming } \\
\text { impairment, repetition } \\
\text { impairment }\end{array}$ \\
\hline Kranick et al. (2011) & 64 & $8(13)$ & Speech symptoms \\
\hline Moene et al. (2002) & 45 & $6(13)$ & Speech disturbances \\
\hline Park (2018) & 31 & $10(32)$ & Abnormal speech or voice \\
\hline
\end{tabular}


Speech, language and swallowing impairments in FND

\begin{tabular}{llll}
\hline Saifee et al. (2012) & 26 & $\begin{array}{l}\text { Not specifically stated } \\
(>50)\end{array}$ & $\begin{array}{l}\text { Difficulty speaking/slurred } \\
\text { speech }\end{array}$ \\
& & $\begin{array}{l}\text { Not specifically stated } \\
(<20)\end{array}$ & Difficulty swallowing \\
Sharma et al. $(2017)$ & 30 & $4(13)$ & Speech difficulty \\
Stone et al. (2010b) & 107 & $30(27)$ & Slurred speech \\
& & $11(10)$ & Word finding difficulties \\
\hline
\end{tabular}

Table 4: Number of patients (\%) who presented with speech, language or swallowing symptoms in 20 papers which included participant numbers and details of presenting symptoms

Speech and language therapy involvement

Only eight papers report direct speech and language therapy input (13\%). The involvement of SLTs for consultation and assessment for diagnosis was described in six papers $(10 \%)$.

Direct therapy was stated in four papers (6\%), with two papers stating SLT input for both consultation and therapy. Babin and Gross (2002) report a case study in which a participant received direct dysarthria therapy for slurred speech and tongue protrusion. Jacob et al. (2018) report that SLTs were involved in the administration of an interdisciplinary motor retraining program. Czarnecki et al. (2012) simply state "therapy" and do not report on details of the therapy and Haubenberger et al.(2004) state they used "voice and breathing techniques" for a case study of dysarthrophonia although no further details are given.

\section{Discussion}

This scoping review confirms that speech, language and swallowing symptoms do exist in patients with FND. The symptoms themselves, however, have not been the focus of a large amount of the literature. Little empirical research exists regarding the number of patients with FND with these impairments or the effects of SLT input. De Letter et al. (2012) suggest that one difficulty in this area is the "dramatic under-reporting" of functional language 
Speech, language and swallowing impairments in FND

disorders. This was evident in our review in that many papers simply mentioned these symptoms with little attached detail. Although Czarnecki et al. (2012: 248) report that seven of their patients presented with functional speech symptoms, they specifically state that "speech outcomes [are] not included in current analysis". Baizabal-Carvallo and Jankovic (2015:2422), in their analysis of the frequency of functional speech and voice disorders in patients with functional movement disorders, acknowledge the under-reporting of functional communication symptoms and report that "the descriptions often lack detail". This has implications for research and clinical practice as valid conclusions about any included symptoms/treatment cannot be made if sufficient detail is not provided. Future research is required to accurately determine the prevalence of functional communication and swallowing disorders amongst patients with FND in order to direct further research priorities and service development.

One factor which is likely to contribute to the under-reporting of functional speech, language and swallowing disorders is the lack of positive diagnostic criteria. Diagnosis of FND itself is not a diagnosis of exclusion and positive diagnostic criteria for physical symptoms have been validated (Edwards \& Bhatia 2012; Daum et al. 2014). SLTs, however, do not have validated diagnostic criteria. This means that functional communication and swallowing disorders may go under-diagnosed and consequently under-reported. Currently, functional communication and swallowing disorders are a diagnosis of exclusion (De Letter et al. 2012; Teodoro et al. 2018; Kim et al. 2018). Further research is needed to validate a set of positive diagnostic criteria for SLTs to use both within clinical and research practice.
Although validated diagnostic criteria for these symptoms do not currently exist, there are clinical indicators which might suggest the presence of a functional communication disorder (see Table 5). 
Speech, language and swallowing impairments in FND

Clinical indicators of a functional communication disorder

Inconsistencies or incongruence with:

- Known neurological conditions

- Different audiences

- Symptoms or types of errors made

- Varying topics, settings or assessment tasks

- Oral-motor examination compared with speech produced

- Known patterns of fatigue

Distractibility or suggestibility of symptoms

Rapid improvement to symptomatic therapy

Presence of other functional neurological symptoms

Table 5: List of clinical indicators which might suggest a functional communication disorder based on Duffy (2016), Stone et al. (2016) and Chung et al. (2018)

These listed indicators need to be considered within the context of a thorough neurological examination (Gill and Damann 2015). An interdisciplinary approach is required for accurate diagnosis and management of FND (Healthcare Improvement Scotland 2012). SLTs are well placed to contribute to the diagnostic assessment of a patient with FND given their specialist knowledge of communication and swallowing disorders. The validation of positive diagnostic criteria, however, would assist in the clear and consistent reporting of these.

The majority of the included papers reported on speech symptoms but were described by professionals other than SLTs. This means that the accuracy of these symptoms being a form of dysarthria, as opposed to a communication impairment in general, cannot be guaranteed. The inclusion of a speech section on standardised rating scales for FND suggests that speech is considered an important and common enough factor in the presentation of functional disorders to warrant rating. The scales developed by Hinson et al. (2005) and Nielson et al. (2017a), however, do not comment on what "speech" means or which parameters should be 
Speech, language and swallowing impairments in FND

rated. Nielson et al. (2017a) tested their scale with physiotherapists as raters because they highlight that these healthcare professionals are those who treat the patients, as opposed to the diagnosing neurologist. It is these professionals, therefore, who will require the rating scales in order to measure outcomes of treatment. This highlights a gap for further research in that current rating scales should be tested for reliability when completed by SLTs.

Conversely, a rating scale specific to speech, language and swallowing impairments could be created and validated. This would assist in improving the accurate and consistent reporting of speech and language therapy symptoms in the literature and within clinical care.

Another challenge in the reporting of functional speech, language and swallowing impairments is the varying use of terminology used to describe FND. The use of various terms in the literature provided difficulties when deciding on inclusion or exclusion of articles. This is because authors use terms in interchangeable ways. For example, Değirmenci et al. (2012) present a case study in which the patient had gait and speech disturbance. The authors used the term "psychogenic movement disorder" throughout the paper yet concluded that the patient had factitious disorder. This article was, therefore, excluded due to deliberate intent to feign symptoms. This highlights, however, both the challenge of accurate diagnosis and also the confusing availability of so many terms. This is reflected in the fact that almost a third of the papers published in the 2010s used more than one term within their reports. This confusion is likely to impact on clinical practice. If the literature uses various terms, SLTs cannot readily search for available evidence to inform management of this patient group. Difficulties engaging in professional conversations amongst SLTs regarding FND may also exist due to the wide variety of terminology used.

Prominent authors in the field of FND have praised the inclusion of the term "functional" in the DSM-5 and encourage its use as the predominant term (Ganos et al. 2014a; Demartini et 
Speech, language and swallowing impairments in FND

al. 2016). Within this scoping review, "functional" was the term used most frequently in recent years. This reflects the change in categorisation in the DSM-5 in that a psychological stressor is no longer deemed necessary for classification. The RCSLT's Clinical Guidelines (2005) uses the term "psychogenic" in relation to dysfluency and there is no mention of FND within these guidelines. SLTs as a profession will need to engage in discussions around terminology as it will impact on the consistent and clear reporting of functional communication and swallowing symptoms, as outlined above. A consensus agreement regarding appropriate terminology to use going forwards would be useful for both practising clinicians and researchers.

Interdisciplinary treatment of FND is widely recognised as important both for successful diagnosis but also management (Czarnecki et al. 2012; Saifee et al. 2012; McCormack et al. 2014). Amongst the publications found in the literature review there was a consensus that SLTs do have a role to play in the management of patients with FND, despite none of the papers addressing this directly (Rosebush and Mazurek 2011; Healthcare Improvement Scotland 2012; Stone et al. 2016b; Jokel and Wolf 2017; Chung et al. 2018). The role of occupational therapists has recently been acknowledged with regards to FND (Gardiner et al. 2017). It is recognised, however, that consensus guidelines and further research is required regarding occupational therapy input. Evidence is emerging that suggests physiotherapy is effective in the treatment of FND (Nielsen et al. 2017b). Given that physiotherapy is effective to treat functional physical symptoms, it is feasible to suggest that speech and language therapy could be effective to treat functional speech, language and swallowing symptoms. Although only a small number of publications in this review reported the direct input of SLTs, it is possible that this is due to under-reporting as opposed to underutilisation of the profession. As the focus of many of the papers was functional movement disorders, it 
Speech, language and swallowing impairments in FND

is possible that SLT involvement occurred but was not included in the reports. None of the papers in the review assessed the effectiveness of speech and language therapy input; however Stone et al. (2016b: 673) state that "experience suggests that symptomatic speech therapy can be helpful in a large proportion of cases". Further research is needed to assess both the short- and long-term impact of specific speech and language therapy techniques in order to inform future evidence-based clinical practice.

Another area in which functional speech, language and swallowing symptoms are likely under-reported is with regards to patients with functional strokes. Papers were excluded from this review if they did not explicitly state the presence of one of the above symptoms. It is likely, however, that publications focussing on functional stroke mimics, such as Nazir et al. (2005), would have had patients who presented with functional speech, language or swallowing symptoms; however these symptoms were not included in their analysis. In the UK, patients who are admitted with a suspected stroke are placed on a stroke pathway. National audit targets exist which state that patients should be assessed by all relevant therapies within 72 hours of admission (Royal College of Physicians no date). Anecdotally, this means that patients with functional strokes are often referred to speech and language therapy on stroke units. Key barriers to the effective explanation and commencement of treatment have been identified as a lack of training and possible negative attitudes from healthcare professionals (Stone et al. 2016a). Studies on the attitudes of interdisciplinary members towards functional disorders have highlighted that professionals have limited selfrated knowledge on how to treat FND and also suggest there is a need for clear guidelines in the assessment and management of these patients (Espay et al. 2009; Edwards et al. 2012). Currently no literature exists on SLTs' attitudes and experiences of treating FND. Given that 
Speech, language and swallowing impairments in FND

patients with functional strokes are being referred to speech and language therapy, this is a key avenue for further research.

A common misconception about FND is that patients are "making it up" which can contribute to negative attitudes from healthcare professionals (Ahern et al. 2009). Patients with FND have expressed frustration about not having their symptoms believed and the high levels of uncertainty regarding diagnostic labels (Nettleton et al. 2005). Consequently, they often experience difficulties with physical, emotional and social aspects of their lives, including unemployment and withdrawing from friends (Carson et al. 2010; Epstein et al. 2016).

Given the significant and wide ranging impacts patients with FND experience and the current lack of research or guidance for SLTs, it is vital that further research and clinical guidelines are developed for this patient group in order to optimise their outcomes.

\section{Strengths and limitations}

A strength of the scoping review method is that it covers a wide range of publications, as is clear in this scoping review with the inclusion of 13 different research methods. A limitation, however, is that the papers are not quality assessed and this must be considered when reviewing the results. Secondly, only papers published in the English language were included. This means that relevant papers may exist in languages other than English. Another limitation was due to the challenges faced when trying to include and interpret the wide range of terminology used within this field. When interpretation is involved, a degree of subjectivity is inherently present. Although copious searching for relevant terms and opinions of multiple authors was sought it is possible that other researchers may have interpreted terminology differently from how it has been interpreted in this review. A possible way of making this more robust would be to conduct a consultation phase with 
Speech, language and swallowing impairments in FND

experts in the field of FND, for example SLTs, neurologists and psychologists. This would provide further information on the range of terminology used in practice and may have highlighted further search terms to include.

\section{Conclusions}

This scoping review highlights that functional speech, language and swallowing symptoms other than dysphonia, foreign accent syndrome and dysfluency do exist in patients with FND. It is clear, however, that this is a largely under-researched area. Further research and consensus guidelines are required in order to agree on terminology to be used consistently within clinical practice and to develop a set of positive diagnostic criteria. Focussed descriptive research is required in order to accurately report on numbers of patients with FND with speech, language or swallowing symptoms. Empirical research is also needed in order to assess the effectiveness of direct speech and language therapy involvement in order to improve outcomes for patients with FND in the future. 
Speech, language and swallowing impairments in FND

\section{References}

Ahern, L., Stone, J. and Sharpe, M., 2009, Attitudes of neuroscience nurses toward patients with conversion symptoms. Psychosomatics, 50(4), 336-339.

Akyüz, F., Gökalp, P. G., Erdİman, S., Oflaz, S. and Karşidağ, Ç., 2017, Conversion disorder comorbidity and childhood trauma. Archives of Neuropsychiatry, 54, 15-20.

Arksey, H. \& O’Malley, L., 2005, Scoping studies: towards a methodological framework. International Journal of Social Research Methodology, 8(1), 19-32.

Artto, V., Putaala, J., Strbian, D., Meretoja, A., Piironen, K., Liebkind, R., Silvennoinen, H., Atula, S. and Happola, O., 2012, Stroke mimics and intravenous thrombolysis. Annals of Emergency Medicine, 59(1), 27-32.

American Psychiatric Association, 2013, Diagnostic and Statistical Manual of Mental Disorders 5th ed. (Arlington, VA: American Psychiatric Publishing).

Babin, P. and Gross, P., 2002, Traumatic brain injury when symptoms don't add up: Conversion and malingering in the rehabilitation setting. Journal of Rehabilitation, 68(2), 4-13.

Baizabal-Carvallo, J. F. and Jankovic, J., 2017, Functional (psychogenic) stereotypies. Journal of Neurology, 264, 1482-1487.

Baizabal-Carvallo, J.F. and Jankovic, J., 2015, Speech and voice disorders in patients with psychogenic movement disorders. Journal of Neurology, 262(11),.2420-2424.

Baker, J. 2016, Functional voice disorders: Clinical presentations and differential diagnosis. In M. Hallet, J. Stone, and A. Carson, (eds), Handbook of Clinical Neurology Functional Neurologic Disorders (Amsterdam: Elsevier), pp. 389-405.

Baumann, A. and Katz, P. 2016, Functional disorders of swallowing. In M. Hallet, J. Stone, and A. Carson, (eds), Handbook of Clinical Neurology Functional Neurologic Disorders (Amsterdam: Elsevier), pp. 483-488.

Cantello, R., Boccagni, C., Comi, C., Civardi, C. and Monaco, F., 2001, Diagnosis of psychogenic paralysis: The role of motor evoked potentials. Journal of Neurology, $\mathbf{2 4 8 ,}$ 
Speech, language and swallowing impairments in FND

889-897.

Carson, A., Brown, R., David, A., Duncan, R., Edwards, M., Goldstein, L., Grunewald, R., Howlett, S., Kanaan, R., Mellers, J., Nicholson, T., Reuber, M., Schrag, A., Stone, J. and Voon, V., 2012, Functional (conversion) neurological symptoms: research since the millennium. Journal of Neurology, Neurosurgery, and Psychiatry, 83(8), 842-50.

Carson, A., Stone, J., Hibberd, C., Murray, G., Duncan, R., Coleman, R., Warlow, C., Roberts, R., Pelosi, A., Cavanagh, J., Matthews, K., Goldbeck, R., Hansen, C., and Sharpe, M., 2010, Disability, distress and unemployment in neurology outpateitns with symptoms 'unexplained by organic disease'. Journal of Neurology, Neurosurgery and Psychiatry, 82:810-813.

Chen, Y., Bogosavljevic, V., Leys, D., Jovanovic, D., Beslac-Bumbasirevic, L., and Lucas, C., 2011, Intravenous thrombolytic therapy in patients with stroke mimics: Baseline characteristics and safety profile. European Journal of Neurology, 18(10),1246-1250.

Chung, D., Wettroth, C., Hallett, M. and Maurer, C., 2018, Functional speech and voice disorders: Case series and literature review. Movement Disorders Clinical Practice, 5(3), 312-316.

Cubo, E., Hinson, V., Goetz, C., Ruiz, P., Yebenes, J., Marti, M., Oroz, M., Linazasoro, G., Chacón, J., Váquez, A., Lópex del Val, J., Leurgans, S. and Wuu, J., 2005, Transcultural comparison of psychogenic movement disorders. Movement Disorders, 20(10), 13431345.

Czarnecki, K., Thompson, J., Seime, R., Geda, Y., Duffy, J. and Ahlskog, J., 2012, Functional movement disorders: Successful treatment with a physical therapy rehabilitation protocol. Parkinsonism and Related Disorders, 18(3), 247-251.

Daum, C., Hubschmid, M. and Aybek, S., 2014,. The value of 'positive' clinical signs for weakness, sensory and gait disorders in conversion disorder: A systematic and narrative review. Journal of Neurology, Neurosurgery and Psychiatry, 85,180-190.

De Letter, M., Van Borsel, J., Penen, K., Hemelsoet, D., Vervaet, V., Meurs, A. and Santens, P., 2012, Non-organic language disorders: Three case reports. Aphasiology, 26(7), 867- 
Speech, language and swallowing impairments in FND

879.

Değirmenci, Y., Güleç Oyekçin, D. and Karaman, H.I.Ö., 2012, A case of psychogenic movement disorders: Dark side of neurology and neuropsychiatry. Archives of Neuropsychiatry, 49, 235-237.

Demartini, B., D’Agostino, A. and Gambini, O., 2016, From conversion disorder (DSM-IVTR) to functional neurological symptom disorder (DSM-5): When a label changes the perspective for the neurologist, the psychiatrist and the patient. Journal of the Neurological Sciences, 360, 55-56.

Duffy, J.R., 2016, Functional speech disorders: clinical manifestations, diagnosis and management. In M. Hallet, J. Stone, and A. Carson, (eds), Handbook of Clinical Neurology Functional Neurologic Disorders (Amsterdam: Elsevier), pp. 379-388.

Edwards, M.J. and Bhatia, K.P., 2012, Functional (psychogenic) movement disorders: Merging mind and brain. The Lancet Neurology, 11(3), 250-260.

Edwards, M.J., Stone, J. and Nielsen, G., 2012, Physiotherapists and patients with functional (psychogenic) motor symptoms: a survey of attitudes and interest. Journal of Neurology, Neurosurgery, and Psychiatry, 83(6), 655-658.

Epstein, S., Maurer, C., LaFaver, K., Ameli, R., Sinclair, S. and Hallett, M., 2016, Insights into chronic functional movement disorders: The value of qualitative psychiatric interviews. Psychosomatics, 57, 566-575.

Ertan, S., Uluduz, D., Özekmekçi, S., Kiziltan, G., Ertna, T., Yalçinkaya, C. and Özkara, Ç., 2009, Clinical characteristics of 49 patients with psychogenic movement disorders in a tertiary clinic in Turkey. Movement Disorders, 24(5), 759-782.

Espay, A.J., Goldenhar, L., Voon, V., Schrag, A., Burton, N., and Lang, A., 2009, Opinions and clinical practices related to diagnosing and managing patients with psychogenic movement disorders: An international survey of movement disorder society members. Movement Disorders, 24(9), 1366-1374.

Factor, S., Podskalny, G. and Molho, E., 1995, Psyschogenic movement disorders: Frequency, clinical profile and characteristics. Journal of Neurology, Neurosurgery and 
Speech, language and swallowing impairments in FND

Psychiatry, 59, 406-412.

Fasano, A., Valadas, A., Bhatia, K., Prashanth, L., Lang, A., Munhoz, R., Morgante, F., Tarsy, D., Duker, A., Girlanda, P., Bentivoglio, A. and Espay, A., 2012, Psychogenic facial movement disorders: clinical features and associated conditions. Movement Disorders, 27(12), 1544-1551.

Ganos, C., Erro, R., Bhatia, K. and Tinazzi, M., 2014a, Comment on psychogenic versus functional movement disorders. Movement Disorders, 29(13), 1696-1696.

Ganos, C., Aguirregomozcorta, M., Batla, A., Stamelou, M., Schwingenschuh, P., Münchau, A., Edwards, M. J. and Bhatia, K. P., 2014b, Psychogenic paroxysmal movement disorders - Clinical features and diagnostic clues. Parkinsonism and Related Disorders, 20, 41-46.

Gardiner, P., MacGregor, L., Carson, A. and Stone, J., 2017, Occupational therapy for functional neurological disorders: A scoping review and agenda for research. CNS Spectrums, 1-8.

Gargalas, S., Weeks, R., Khan-Bourne, N., Shotbolt, P., Simblett, S., Ashraf, L., Doyle, C., Bancroft, V. and David, A., 2017, Incidence and outcome of functional stroke mimics admitted to a hyperacute stroke unit. Journal of Neurology Neurosurgery and Psychiatry, 0, 1-5.

Gibson, L. and Whiteley, W., 2013, The differential diagnosis of suspected stroke: A systematic review. Journal of Royal College of Physicians of Edinburgh, 43, 114-118.

Gill, D. J. and Damann, K. M., 2015, Language dysfunction. Continuum, 21(3), 627-645.

Guillan, M., Alonso-Canovas, A., Gonzalez-Valcarcel, J., Barragan, N., Caldentey, J., Hernandez-Medrano, I., DeFilipe-Mimbrera, A., Sanchez-Gonzalez, V., Terecoasa, E., Alonso de Leciñana, M. and Masjuan, J., 2012, Stroke mimics treated with thrombolysis: Further evidence on safety and distinctive clinical features. Cerebrovascular Diseases, 34(2), 115-120.

Haubenberger, D., Vigl, M., Busslinger, I., Denk, D., Fertl, E. and Auff, E., 2004, Psychogenic or non-psychogenic dysarthrophonia? Movement Disorders, 
Speech, language and swallowing impairments in FND

19(Supplement 9), S416.

Healthcare Improvement Scotland, 2012, Stepped Care for Functional Neurological Symptoms. [online] Available:

http://www.healthcareimprovementscotland.org/our_work/long_term_conditions/neurol ogical_health_services/neurological_symptoms_report.aspx. [accessed 30 ${ }^{\text {th }}$ July 2018).

Hinson, V.K., Cubo, E., Comella, C., Goetz, C. and Leurgans, S., 2005, Rating scale for psychogenic movement disorders: Scale development and clinimetric testing. Movement Disorders, 20(12), 1592-1597.

Jacob, A. E., Kaelin, D. L., Roach, A. R., Ziegler, C. H. and LaFaver, K., 2018, Motor retraining (MoRe) for functional movement disorders: Outcomes from a 1-week multidisciplinary rehabilitation program. Physical Medicine and Rehabilitation, 1-9.

Jokel, R. and Wolf, U., 2017, When a duck is not a duck: Non-organic bases for aphasia and dementia. Aphasiology, 31(1), 100-121.

Kim, T. S. Y., Munshi, T. and Hussain, M., 2018, Resolution of severe psychogenic dysphagia with ECT in an elderly patient. International Psychogeriatrics, 30(7), 10811083.

Kranick, S., Ekanayake, V., Martinez, V., Arneli, R., Hallett, M. and Voon, V., 2011, Psychopathology and psychogenic movement disorders. Movement Disorders, 26(10), 1844-1850.

Levac, D., Colquhoun, H. and O’Brien, K., 2010, Scoping studies: Advancing the methodology. Implementation science, 5(69), 1-9.

McCormack, R., Moriarty, J., Mellers, J., Shotbolt, P., Pastena, R., Landes, N., Goldstein, L., Fleminger, S. and David, A., 2014, Specialist inpatient treatment for severe motor conversion disorder: A retrospective comparative study. Journal of Neurology, Neurosurgery, and Psychiatry, 85, 895-898.

Moene, F.C., Spinhoven, P., Hoogduin, K. and van Dyck, R., 2002, A randomised controlled clinical trial on the additional effect of hypnosis in a comprehensive treatment programme for in-patients with conversion disorder of the motor type. Psychotherapy 
Speech, language and swallowing impairments in FND

and Psychosomatics, 71(2), 66-76.

Nazir, F., Lees, K. and Bone, I., 2005, Clinical features associated with medically unexplained stroke-like symptoms presenting to an acute stroke unit. European Journal of Neurology, 12, 81-85.

Nettleton, S., Watt, I., O'Malley, L. and Duffey, P., 2005, Understanding the narratives of people who live with medically unexplained illness', Patient Education and Counseling, 56(2), 205-210.

Nielsen, G., Ricciardi, L., Meppelink, A., Holt, K., Teodoro, T., Edwards, M., 2017a, A simplified version of the Psychogenic Movement Disorders Rating Scale: The Simplified Functional Movement Disorders Rating Scale (S-FMDRS). Movement Disorders Clinical Practice, 38(1), pp.42-49.

Nielson, G., Buszewicz, M., Stevenson, F., Hunter, R., Holt, K., Dudziec, M., Ricciardi, L., Marsden, J., Joyce, E., Edwards, M., 2017b, Randomised feasibility study of physiotherapy for patients with functional motor symptoms. Neuropsychiatry, $\mathbf{8 8}, 484$ 490.

Park, J. E., 2018, Clinical characteristics of functional movement disorders: A clinic-based study. Tremor and Other Hyperkinetic Movements, 8, 1-5.

Parry, A.M., Murray, B., Hart, Y. and Bass, C., 2006, Audit of resource use in patients with non-organic disorders admitted to a UK neurology unit. Journal of Neurology, Neurosurgery \& Psychiatry, 77(10), 1200-1201.

Peters, M., Godfrey, C., Khalil, H., McInerney, P., Parker, D. and Soares, C., 2015, Guidance for conducting systematic scoping reviews. International Journal of Evidence-Based Healthcare, 13(3), 141-6.

Pham, M.T., Rajić, A., Greig, J., Sargeant, J., Papadopoulos, A and McEwen, S., 2014, A scoping review of scoping reviews: Advancing the approach and enhancing the consistency. Research Synthesis Methods, 5(4),371-385.

Rosebush, P.I. and Mazurek, M.F., 2011, Treatment of conversion disorder in the 21st century: Have we moved beyond the couch? Current Treatment Options in Neurology, 
Speech, language and swallowing impairments in FND

13(3), 255-266.

Royal College of Physicians, no date, Sentinal Stroke National Audit Programme (SSNAP.) [online] Available: https://www.strokeaudit.org/results/Clinical-audit/NationalResults.aspx [accessed on $12^{\text {th }}$ October 2018].

Royal College of Speech and Language Therapists, 2018, Clinical Resources: Dysphagia Introduction. [online] Available:

https://www.rcslt.org/clinical_resources/dysphagia/introduction [accessed on $30^{\text {th }}$ July 2018].

Royal College of Speech and Language Therapists, 2005, Clinical Guidelines (Oxon: Speechmark Publishing Ltd).

Saifee, T.A., Kassavetis, P., Pareés, I., Kojovic, M., Fisher, L., Morton, L., Foong, J., Price, G., Joyce, E. and Edwards, M.., 2012, Inpatient treatment of functional motor symptoms: A long-term follow-up study. Journal of Neurology, 259(9), 1958-1963.

Sharma, V. D., Jones, R. and Factor, S. A., 2017, Psychodynamic psychotherapy for functional (psychogenic) movement isorders. Journal of Movement Disorders, 10(1), $40-44$.

Stone, J., Carson, A. and Hallett, M., 2016a, Explanation as treatment for functional neurological disorders. In M. Hallet, J. Stone, and A. Carson, (eds), Handbook of Clinical Neurology Functional Neurologic Disorders (Amsterdam: Elsevier), pp. 543553.

Stone, J., Hoeritzauer, I., Gelauff, J., Lehn, A., Gardiner, P., van Fils, A. and Carson, A., 2016b, Functional disorders in neurology: Case studies. Neurologic Clinics, 34(3), 667681.

Stone, J., Carson, A., Duncan, R., Roberts, R., Warlow, C., Hibberd, C., Coleman, R., Cull, R., Murray, G., Pelosi, A., Cavanagh, J., Matthews, K., Goldbeck, R., Smyth, R., Walker, J. and Sharpe, M., 2010a, Who is referred to neurology clinics? - The diagnoses made in 3781 new patients. Clinical Neurology and Neurosurgery, 112(9), 747-751.

Stone, J., Warlow, C. and Sharpe, M., 2010b, The symptom of functional weakness: A 
Speech, language and swallowing impairments in FND

controlled study of 107 patients. Brain, 133, 1537-1551.

Stone, J., Carson, A. and Sharpe, M., 2005, Functional symptoms in neurology: Management. Journal of Neurology, Neurosurgery \& Psychiatry, 76(Suppl 1), i13-i21.

Teodoro, T., Edwards, M. J. and Isaacs, J. D., 2018, A unifying theory for cognitive abnormalities in functional neurological disorders, fibromyalgia and chronic fatigue syndrome: Systematic review. Cognitive Neurology, 0, 1-12.

Vroomen, P., Buddingh, M., Luijckx, G., De Keyser, J., 2008, The incidence of stroke mimics among stroke department admissions in relation to age group. Journal of Stroke and Cerebrovascular Diseases, 17(6), 418-422. 
Speech, language and swallowing impairments in FND

\section{Appendix I: List of search terms}

speech

language

swallowing

slurred speech

dysarthria

*phasia

dysfluency

stuttering

*phonia

dysphagia

word finding difficulties

deglutition

anomia

functional neurological symptom*

functional neurological disorder*

psychogenic

conversion disorder*

somatoform

somati?ation

non-organic

non organic

psychosomatic 
Speech, language and swallowing impairments in FND

medically unexplained symptoms

dissociative disorder*

factitious disorder*

factitious disease

malingering

munchausen

ganser syndrome

psychomotor disorder*

inpatient*

hyper acute stroke unit

hyperacute stroke unit

acute stroke unit

accident and emergency

emergency room

ward

A\&E 
Speech, language and swallowing impairments in FND: Data extraction chart

\begin{tabular}{|c|c|c|c|c|c|c|c|c|}
\hline $\begin{array}{l}\text { Author } \\
\text { and year }\end{array}$ & Country & Aim & $\begin{array}{l}\text { Research } \\
\text { Method }\end{array}$ & $\begin{array}{l}\text { Terminology } \\
\text { of diagnoses }\end{array}$ & Setting & $\begin{array}{l}\text { Treatment } \\
\text { approach }\end{array}$ & SLT symptoms & SLT involvement \\
\hline $\begin{array}{l}\text { Afolabi et } \\
\text { al. (2016) }\end{array}$ & USA & $\begin{array}{l}\text { To describe a case } \\
\text { report of a patient } \\
\text { who developed } \\
\text { conversion } \\
\text { disorder post- } \\
\text { operatively }\end{array}$ & Case report & $\begin{array}{l}\text { Conversion } \\
\text { disorder }\end{array}$ & $\begin{array}{l}\text { Operating } \\
\text { theatre }\end{array}$ & Not stated & $\begin{array}{l}\text { Difficulty } \\
\text { speaking }\end{array}$ & Not stated \\
\hline $\begin{array}{l}\text { Akyüz et } \\
\text { al. (2017) }\end{array}$ & Turkey & $\begin{array}{l}\text { To examine the } \\
\text { socio- } \\
\text { demographic and } \\
\text { clinical } \\
\text { characteristics, } \\
\text { the presence of } \\
\text { comorbidity, and } \\
\text { the link with } \\
\text { childhood } \\
\text { traumatic } \\
\text { experiences in } \\
\text { patients with } \\
\text { conversion } \\
\text { disorder }\end{array}$ & Questionnaires & $\begin{array}{l}\text { Conversion } \\
\text { disorder }\end{array}$ & $\begin{array}{l}\text { Psychiatric } \\
\text { outpatient } \\
\text { clinic }\end{array}$ & $\begin{array}{l}\text { Psychiatric } \\
\text { therapy }\end{array}$ & $\begin{array}{l}\text { Aphasia in } 58 / 60 \\
\text { patients }(97 \%)\end{array}$ & Not stated \\
\hline $\begin{array}{l}\text { Al- } \\
\text { Samarrai } \\
\text { et al. } \\
(2001) \\
\end{array}$ & USA & $\begin{array}{l}\text { To present a case } \\
\text { report of a patient } \\
\text { with involuntary } \\
\text { phrase repetition }\end{array}$ & Case report & $\begin{array}{l}\text { Conversion } \\
\text { disorder and } \\
\text { functional }\end{array}$ & $\begin{array}{l}\text { Emergency } \\
\text { room }\end{array}$ & $\begin{array}{l}\text { Amobarbital } \\
\text { interview }\end{array}$ & $\begin{array}{l}\text { Palilalia, writing } \\
\text { with letter or } \\
\text { word repetition }\end{array}$ & $\begin{array}{l}\text { Evaluation of } \\
\text { presentation }\end{array}$ \\
\hline $\begin{array}{l}\text { Andrade et } \\
\text { al. (2009) }\end{array}$ & India & $\begin{array}{l}\text { To describe two } \\
\text { case reports of } \\
\text { patients with } \\
\text { conversion } \\
\text { disorder }\end{array}$ & Case reports & $\begin{array}{l}\text { Conversion } \\
\text { disorder }\end{array}$ & Not stated & $\begin{array}{l}\text { Systematic } \\
\text { enhancement of } \\
\text { functioning }\end{array}$ & Inability to speak & $\begin{array}{l}\text { No however } \\
\text { authors state they } \\
\text { adopted speech } \\
\text { therapy } \\
\text { techniques: Direct } \\
\text { therapy focussing } \\
\text { on producing } \\
\text { vocalisations then } \\
\text { moulding into }\end{array}$ \\
\hline
\end{tabular}


Speech, language and swallowing impairments in FND: Data extraction chart

\begin{tabular}{|c|c|c|c|c|c|c|c|c|}
\hline $\begin{array}{l}\text { Author } \\
\text { and year }\end{array}$ & Country & Aim & $\begin{array}{l}\text { Research } \\
\text { Method }\end{array}$ & $\begin{array}{l}\text { Terminology } \\
\text { of diagnoses }\end{array}$ & Setting & $\begin{array}{l}\text { Treatment } \\
\text { approach }\end{array}$ & SLT symptoms & SLT involvement \\
\hline & & & & & & & & $\begin{array}{l}\text { recognisable } \\
\text { words }\end{array}$ \\
\hline $\begin{array}{l}\text { Artto et al. } \\
\text { (2012) }\end{array}$ & Finland & $\begin{array}{l}\text { To characterise } \\
\text { cases classified as } \\
\text { stroke mimics }\end{array}$ & $\begin{array}{l}\text { Prospective } \\
\text { analysis }\end{array}$ & $\begin{array}{l}\text { Conversion } \\
\text { disorder }\end{array}$ & Stroke unit & Not stated & $\begin{array}{l}1 / 14 \text { stroke mimic } \\
\text { patients with } \\
\text { conversion } \\
\text { disorder had } \\
\text { dysarthria and } \\
1 / 14 \text { had } \\
\text { dysphasia }\end{array}$ & Not stated \\
\hline $\begin{array}{l}\text { Babin and } \\
\text { Gross } \\
(2002)\end{array}$ & USA & $\begin{array}{l}\text { To review the } \\
\text { literature on } \\
\text { conversion and } \\
\text { malingering, to } \\
\text { discuss the most } \\
\text { frequently } \\
\text { administered tests } \\
\text { used for } \\
\text { assessment and to } \\
\text { present two case } \\
\text { reports }\end{array}$ & Case reports & $\begin{array}{l}\text { Conversion } \\
\text { disorder }\end{array}$ & $\begin{array}{l}\text { Hospital } \\
\text { admission } \\
\text { to acute } \\
\text { rehabilitati } \\
\text { on then } \\
\text { outpatient } \\
\text { brain injury } \\
\text { programme }\end{array}$ & $\begin{array}{l}\text { Speech and } \\
\text { language therapy, } \\
\text { occupational } \\
\text { therapy, } \\
\text { psychotherapy, } \\
\text { group cognitive } \\
\text { therapy, } \\
\text { adjustment group, } \\
\text { community re- } \\
\text { entry group }\end{array}$ & $\begin{array}{l}\text { Anomia, slurred } \\
\text { speech, prominent } \\
\text { tongue protrusion }\end{array}$ & $\begin{array}{l}\text { Administered } \\
\text { cognitive tests. } \\
\text { Provided direct } \\
\text { treatment with a } \\
\text { pseudo-scientific } \\
\text { explanation }\end{array}$ \\
\hline $\begin{array}{l}\text { Baizabal- } \\
\text { Carvallo } \\
\text { and } \\
\text { Jankovic } \\
(2015)\end{array}$ & USA & $\begin{array}{l}\text { To characterise } \\
\text { the } \\
\text { phenomenology, } \\
\text { frequency, and } \\
\text { correlates of } \\
\text { psychogenic } \\
\text { speech and voice } \\
\text { disorders in a } \\
\text { cohort of patients } \\
\text { with psychogenic } \\
\text { movement } \\
\text { disorders }\end{array}$ & $\begin{array}{l}\text { Retrospective } \\
\text { review of } \\
\text { medical notes } \\
\text { and videos }\end{array}$ & $\begin{array}{l}\text { Psychogenic } \\
\text { movement } \\
\text { disorder, } \\
\text { psychogenic } \\
\text { speech and } \\
\text { voice disorder }\end{array}$ & $\begin{array}{l}\text { Movement } \\
\text { disorders } \\
\text { clinic }\end{array}$ & $\begin{array}{l}\text { Pharmacotherapy, } \\
\text { psychotherapy, } \\
\text { stress } \\
\text { management }\end{array}$ & $\begin{array}{l}30 / 182 \text { had } \\
\text { psychogenic } \\
\text { speech and voice } \\
\text { disorder } \\
(16.48 \%) .4 / 182 \\
\text { had speech arrests } \\
(2.20 \%)\end{array}$ & Not stated \\
\hline Baizabal- & USA & To identify the & Retrospective & Functional, & Movement & Not stated & Abnormal speech & Not stated \\
\hline
\end{tabular}


Speech, language and swallowing impairments in FND: Data extraction chart

\begin{tabular}{|c|c|c|c|c|c|c|c|c|}
\hline $\begin{array}{l}\text { Author } \\
\text { and year }\end{array}$ & Country & Aim & $\begin{array}{l}\text { Research } \\
\text { Method }\end{array}$ & $\begin{array}{l}\text { Terminology } \\
\text { of diagnoses }\end{array}$ & Setting & $\begin{array}{l}\text { Treatment } \\
\text { approach }\end{array}$ & SLT symptoms & SLT involvement \\
\hline $\begin{array}{l}\text { Carvallo } \\
\text { and } \\
\text { Jankovic } \\
(2017)\end{array}$ & & $\begin{array}{l}\text { frequency and } \\
\text { clinical } \\
\text { characteristics of } \\
\text { functional } \\
\text { stereotypies and } \\
\text { contrast their } \\
\text { clinical features } \\
\text { with classic } \\
\text { tardive dyskinesia }\end{array}$ & analysis & psychogenic & $\begin{array}{l}\text { disorders } \\
\text { clinic }\end{array}$ & & $\begin{array}{l}\text { in } 4 / 9 \text { patients } \\
(44 \%)\end{array}$ & \\
\hline $\begin{array}{l}\text { Barofsky } \\
\text { and } \\
\text { Fontaine } \\
\text { (1998) }\end{array}$ & USA & $\begin{array}{l}\text { To evaluate } \\
\text { whether patients } \\
\text { with psychogenic } \\
\text { dysphagia are } \\
\text { likely to be } \\
\text { diagnosed as or } \\
\text { resemble eating } \\
\text { disorder patients }\end{array}$ & $\begin{array}{l}\text { Self-report } \\
\text { questionnaires } \\
\text { and } \\
\text { comparison of } \\
\text { surface } \\
\text { electro- } \\
\text { myography } \\
\text { with various } \\
\text { patient groups }\end{array}$ & Psychogenic & Test setting & Not stated & Dysphagia & Not stated \\
\hline $\begin{array}{l}\text { Bryant and } \\
\text { Das } \\
(2012)\end{array}$ & Australia & $\begin{array}{l}\text { To present a case } \\
\text { report of the } \\
\text { neural circuitry } \\
\text { associated with } \\
\text { the recovery of } \\
\text { chronic } \\
\text { conversion } \\
\text { disorder }\end{array}$ & Case report & $\begin{array}{l}\text { Conversion } \\
\text { disorder and } \\
\text { hysterical }\end{array}$ & $\begin{array}{l}\text { Psychology } \\
\text { outpatients }\end{array}$ & $\begin{array}{l}\text { Counselling, } \\
\text { psychotherapy }\end{array}$ & Hysterical mutism & Not stated \\
\hline $\begin{array}{l}\text { Cantello et } \\
\text { al. }(2001)\end{array}$ & Italy & $\begin{array}{l}\text { To review } \\
\text { patients with a } \\
\text { diagnosis of } \\
\text { psychogenic } \\
\text { paralysis and } \\
\text { review whether } \\
\text { time taken to }\end{array}$ & $\begin{array}{l}\text { Retrospective } \\
\text { review }\end{array}$ & $\begin{array}{l}\text { Psychogenic } \\
\text { paralysis }\end{array}$ & $\begin{array}{l}\text { Neurology } \\
\text { ward }\end{array}$ & $\begin{array}{l}\text { Only stated for } 3 \\
\text { case reports: } \\
\text { psychiatric } \\
\text { counselling, } \\
\text { resolution with } \\
\text { explanation }\end{array}$ & $\begin{array}{l}2 / 21 \text { global } \\
\text { aphasia }(9.52 \%) \text {. } \\
1 / 21 \text { motor } \\
\text { aphasia }(4.76 \%) \\
1 / 21 \text { dysarthria } \\
(4.76 \%)\end{array}$ & Not stated \\
\hline
\end{tabular}


Speech, language and swallowing impairments in FND: Data extraction chart

\begin{tabular}{|c|c|c|c|c|c|c|c|c|}
\hline $\begin{array}{l}\text { Author } \\
\text { and year }\end{array}$ & Country & Aim & $\begin{array}{l}\text { Research } \\
\text { Method }\end{array}$ & $\begin{array}{l}\text { Terminology } \\
\text { of diagnoses }\end{array}$ & Setting & $\begin{array}{l}\text { Treatment } \\
\text { approach }\end{array}$ & SLT symptoms & SLT involvement \\
\hline & & $\begin{array}{l}\text { make the } \\
\text { diagnosis had } \\
\text { changed and } \\
\text { diagnostic tests } \\
\text { used }\end{array}$ & & & & & & \\
\hline $\begin{array}{l}\text { Carter } \\
(1967)\end{array}$ & UK & $\begin{array}{l}\text { To describe three } \\
\text { different types of } \\
\text { functional overlay }\end{array}$ & $\begin{array}{l}\text { Case reports } \\
\text { and opinion }\end{array}$ & $\begin{array}{l}\text { Conversion } \\
\text { reaction, } \\
\text { functional } \\
\text { overlay }\end{array}$ & $\begin{array}{l}\text { Neurology } \\
\text { outpatient }\end{array}$ & $\begin{array}{l}\text { Explanation, } \\
\text { reassurance, } \\
\text { suggestion }\end{array}$ & Mutism & Not stated \\
\hline $\begin{array}{l}\text { Chen et al. } \\
\text { (2011) }\end{array}$ & $\begin{array}{l}\text { France } \\
\text { and } \\
\text { Serbia }\end{array}$ & $\begin{array}{l}\text { To determine the } \\
\text { baseline profile } \\
\text { and the outcome } \\
\text { in patients with } \\
\text { stroke mimics } \\
\text { who received } \\
\text { intravenous } \\
\text { thrombolytic } \\
\text { therapy }\end{array}$ & $\begin{array}{l}\text { Retrospective } \\
\text { analysis of } \\
\text { data }\end{array}$ & $\begin{array}{l}\text { Functional } \\
\text { symptoms, } \\
\text { somatoform } \\
\text { disorders }\end{array}$ & Stroke unit & Not stated & $\begin{array}{l}\text { 2/7 stroke mimic } \\
\text { patients had } \\
\text { dysarthria, } 1 / 7 \\
\text { had aphasia }\end{array}$ & Not stated \\
\hline $\begin{array}{l}\text { Chung et } \\
\text { al. (2018) }\end{array}$ & USA & $\begin{array}{l}\text { To discuss the } \\
\text { characteristics of } \\
\text { functional speech } \\
\text { and voice } \\
\text { disorders }\end{array}$ & $\begin{array}{l}\text { Review and } \\
\text { case reports }\end{array}$ & $\begin{array}{l}\text { Functional } \\
\text { disorders of } \\
\text { speech and } \\
\text { voice }\end{array}$ & Not stated & Not stated & $\begin{array}{l}\text { Childlike } \\
\text { prosody, impaired } \\
\text { speech }\end{array}$ & $\begin{array}{l}\text { States that SLT } \\
\text { involvement can } \\
\text { produce dramatic } \\
\text { improvements to } \\
\text { functional speech } \\
\text { and voice } \\
\text { disorders }\end{array}$ \\
\hline $\begin{array}{l}\text { Cubo et al. } \\
(2005)\end{array}$ & $\begin{array}{l}\text { Spain } \\
\text { and USA }\end{array}$ & $\begin{array}{l}\text { To compare the } \\
\text { phenomenology, } \\
\text { anatomical } \\
\text { distribution and } \\
\text { functional } \\
\text { impairment of } \\
\text { psychogenic } \\
\text { movement }\end{array}$ & $\begin{array}{l}\text { Analysis of } \\
\text { data from } \\
\text { rating scales of } \\
\text { video tapes of } \\
\text { patients with } \\
\text { psychogenic } \\
\text { movement } \\
\text { disorder }\end{array}$ & $\begin{array}{l}\text { Psychogenic } \\
\text { movement } \\
\text { disorder }\end{array}$ & $\begin{array}{l}\text { Medical } \\
\text { centre }\end{array}$ & Not stated & $\begin{array}{l}\text { USA: } 16 / 88 \text { had } \\
\text { speech symptoms } \\
(18.18 \%) . \\
\text { Spain: } 11 / 48 \text { had } \\
\text { speech symptoms } \\
(22.92 \%)\end{array}$ & Not stated \\
\hline
\end{tabular}


Speech, language and swallowing impairments in FND: Data extraction chart

\begin{tabular}{|c|c|c|c|c|c|c|c|c|}
\hline $\begin{array}{l}\text { Author } \\
\text { and year }\end{array}$ & Country & Aim & $\begin{array}{l}\text { Research } \\
\text { Method }\end{array}$ & $\begin{array}{l}\text { Terminology } \\
\text { of diagnoses }\end{array}$ & Setting & $\begin{array}{l}\text { Treatment } \\
\text { approach }\end{array}$ & SLT symptoms & SLT involvement \\
\hline & & $\begin{array}{l}\text { disorders in the } \\
\text { United States of } \\
\text { America (USA) } \\
\text { and Spain }\end{array}$ & & & & & & \\
\hline $\begin{array}{l}\text { Czarnecki } \\
\text { et al. } \\
(2012)\end{array}$ & USA & $\begin{array}{l}\text { 1) To describe the } \\
\text { protocol } \\
\text { conducted in the } \\
\text { Department of } \\
\text { Physical } \\
\text { Medicine and } \\
\text { Rehabilitation for } \\
\text { functional } \\
\text { movement } \\
\text { disorder } \\
\text { 2) To assess short } \\
\text { term and long } \\
\text { term outcomes }\end{array}$ & $\begin{array}{l}\text { Historical } \\
\text { cohort study }\end{array}$ & $\begin{array}{l}\text { Functional } \\
\text { movement } \\
\text { disorder }\end{array}$ & $\begin{array}{l}\text { Tertiary } \\
\text { care centre }\end{array}$ & $\begin{array}{l}\text { Counselling, } \\
\text { physiotherapy, } \\
\text { occupational } \\
\text { therapy, speech } \\
\text { and language } \\
\text { therapy, } \\
\text { psychiatry, } \\
\text { psychology }\end{array}$ & $\begin{array}{l}7 / 60 \text { had } \\
\text { functional speech } \\
\text { disorder } \\
(11.67 \%) \text {. Speech } \\
\text { outcomes not } \\
\text { reported }\end{array}$ & $\begin{array}{l}\text { Consultation and } \\
\text { therapy }\end{array}$ \\
\hline $\begin{array}{l}\text { De Letter } \\
\text { et al. } \\
(2012)\end{array}$ & Belgium & $\begin{array}{l}\text { 1) To present } \\
\text { three case reports } \\
\text { of patients with a } \\
\text { language disorder } \\
\text { that is not } \\
\text { ascribed to } \\
\text { concomitantly } \\
\text { present brain } \\
\text { lesions } \\
\text { 2) To compare the } \\
\text { clinical and } \\
\text { linguistic features } \\
\text { with those of } \\
\text { previously } \\
\text { reported cases of } \\
\text { non-organic }\end{array}$ & Case reports & $\begin{array}{l}\text { Non-organic } \\
\text { language } \\
\text { disorder }\end{array}$ & $\begin{array}{l}\text { Neurology } \\
\text { ward }\end{array}$ & $\begin{array}{l}\text { Pharmacotherapy, } \\
\text { rehabilitation }\end{array}$ & $\begin{array}{l}\text { Mutism, } \\
\text { agrammatism, } \\
\text { phonological } \\
\text { paraphasias, } \\
\text { paralexias, } \\
\text { perseverations, } \\
\text { neologisms, word } \\
\text { finding } \\
\text { difficulties, } \\
\text { infantile language } \\
\text { behaviour, } \\
\text { impaired } \\
\text { repetition, } \\
\text { agraphia }\end{array}$ & Not stated \\
\hline
\end{tabular}


Speech, language and swallowing impairments in FND: Data extraction chart

\begin{tabular}{|c|c|c|c|c|c|c|c|c|}
\hline $\begin{array}{l}\text { Author } \\
\text { and year }\end{array}$ & Country & Aim & $\begin{array}{l}\text { Research } \\
\text { Method }\end{array}$ & $\begin{array}{l}\text { Terminology } \\
\text { of diagnoses }\end{array}$ & Setting & $\begin{array}{l}\text { Treatment } \\
\text { approach }\end{array}$ & SLT symptoms & SLT involvement \\
\hline & & language disorder & & & & & & \\
\hline $\begin{array}{l}\text { Dwyer and } \\
\text { Reid } \\
(2004)\end{array}$ & UK & $\begin{array}{l}\text { To present a case } \\
\text { report of a patient } \\
\text { with Ganser's } \\
\text { syndrome and to } \\
\text { review Ganser's } \\
\text { syndrome }\end{array}$ & $\begin{array}{l}\text { Case report } \\
\text { and review }\end{array}$ & $\begin{array}{l}\text { Ganser's } \\
\text { syndrome }\end{array}$ & $\begin{array}{l}\text { Neurology } \\
\text { ward }\end{array}$ & $\begin{array}{l}\text { Spontaneous } \\
\text { recovery }\end{array}$ & $\begin{array}{l}\text { Alexia, impaired } \\
\text { repetition }\end{array}$ & Not stated \\
\hline $\begin{array}{l}\text { Epstein et } \\
\text { al. (2016) }\end{array}$ & USA & $\begin{array}{l}\text { To conduct } \\
\text { qualitative } \\
\text { interviews in } \\
\text { order to enhance } \\
\text { understanding of } \\
\text { psychologic } \\
\text { aspects of } \\
\text { functional } \\
\text { movement } \\
\text { disorders }\end{array}$ & Interviews & $\begin{array}{l}\text { Functional } \\
\text { movement } \\
\text { disorder }\end{array}$ & Not stated & Not stated & $\begin{array}{l}\text { 6/36 participants } \\
\text { had "functional } \\
\text { speech" }\end{array}$ & Not stated \\
\hline $\begin{array}{l}\text { Ertan et al. } \\
(2009)\end{array}$ & Turkey & $\begin{array}{l}\text { To outline the } \\
\text { clinical } \\
\text { characteristics of } \\
\text { patients with } \\
\text { psychogenic } \\
\text { movement } \\
\text { disorder }\end{array}$ & $\begin{array}{l}\text { Prospective } \\
\text { analysis of } \\
\text { clinical } \\
\text { characteristics }\end{array}$ & $\begin{array}{l}\text { Psychogenic } \\
\text { movement } \\
\text { disorder }\end{array}$ & $\begin{array}{l}\text { Movement } \\
\text { disorders } \\
\text { unit }\end{array}$ & Not stated & $\begin{array}{l}\text { 4/49 had bizarre } \\
\text { speech }(8.16 \%)\end{array}$ & Not stated \\
\hline $\begin{array}{l}\text { Factor et } \\
\text { al. (1995) }\end{array}$ & USA & $\begin{array}{l}\text { To review the } \\
\text { frequency, } \\
\text { clinical profile } \\
\text { and } \\
\text { characteristics of } \\
\text { patients with } \\
\text { psychogenic } \\
\text { movement } \\
\text { disorder }\end{array}$ & $\begin{array}{l}\text { Retrospective } \\
\text { analysis }\end{array}$ & $\begin{array}{l}\text { Psychogenic } \\
\text { movement } \\
\text { disorder }\end{array}$ & $\begin{array}{l}\text { Movement } \\
\text { disorders } \\
\text { clinic }\end{array}$ & $\begin{array}{l}\text { Spontaneous } \\
\text { recovery, } \\
\text { psychology, } \\
\text { physiotherapy, } \\
\text { placebo }\end{array}$ & $\begin{array}{l}1 / 28 \text { had slow } \\
\text { halting voice } \\
(3.57 \%)\end{array}$ & Not stated \\
\hline
\end{tabular}


Speech, language and swallowing impairments in FND: Data extraction chart

\begin{tabular}{|c|c|c|c|c|c|c|c|c|}
\hline $\begin{array}{l}\text { Author } \\
\text { and year }\end{array}$ & Country & Aim & $\begin{array}{l}\text { Research } \\
\text { Method }\end{array}$ & $\begin{array}{l}\text { Terminology } \\
\text { of diagnoses }\end{array}$ & Setting & $\begin{array}{l}\text { Treatment } \\
\text { approach }\end{array}$ & SLT symptoms & SLT involvement \\
\hline $\begin{array}{l}\text { Fasano et } \\
\text { al. (2012) }\end{array}$ & USA & $\begin{array}{l}\text { To examine a } \\
\text { large series of } \\
\text { psychogenic } \\
\text { movement } \\
\text { disorders where } \\
\text { the orofacial } \\
\text { region was } \\
\text { involved to } \\
\text { determine the } \\
\text { clinical features } \\
\text { and associated } \\
\text { disorders and to } \\
\text { highlight their } \\
\text { inconsistency } \\
\text { with recognised } \\
\text { organic } \\
\text { movement } \\
\text { disorders }\end{array}$ & $\begin{array}{l}\text { Retrospective } \\
\text { data analysis }\end{array}$ & $\begin{array}{l}\text { Psychogenic } \\
\text { movement } \\
\text { disorder }\end{array}$ & $\begin{array}{l}\text { Movement } \\
\text { disorders } \\
\text { centres }\end{array}$ & $\begin{array}{l}\text { Pharmacotherapy, } \\
\text { botulinum } \\
\text { neurotoxin, } \\
\text { psychotherapy }\end{array}$ & $\begin{array}{l}11 / 46 \text { had slurred } \\
\text { speech }(23.91 \%) \text {. } \\
7 / 46 \text { had burst of } \\
\text { verbal gibberish } \\
(15.22 \%)\end{array}$ & Not stated \\
\hline $\begin{array}{l}\text { Ganos et } \\
\text { al. (2014) }\end{array}$ & UK & $\begin{array}{l}\text { To describe the } \\
\text { phenomenology, } \\
\text { associated } \\
\text { features and } \\
\text { clinical course of } \\
\text { psychogenic } \\
\text { paroxysmal } \\
\text { movement } \\
\text { disorders }\end{array}$ & $\begin{array}{l}\text { Retrospective } \\
\text { analysis }\end{array}$ & Psychogenic & $\begin{array}{l}\text { Movement } \\
\text { disorders } \\
\text { clinic }\end{array}$ & $\begin{array}{l}\text { Explanation of the } \\
\text { diagnosis, } \\
\text { pharmacotherapy, } \\
\text { multidisciplinary } \\
\text { neuropsychiatric } \\
\text { rehabilitation } \\
\text { program, } \\
\text { botulinum toxin, } \\
\text { placebo }\end{array}$ & $\begin{array}{l}\text { 6/26 patients } \\
(23 \%) \text { had speech } \\
\text { disturbances. } \\
\text { Swallowing } \\
\text { difficulties also } \\
\text { reported however } \\
\text { specific numbers } \\
\text { not stated }\end{array}$ & Not stated \\
\hline $\begin{array}{l}\text { Gargalas } \\
\text { et al. } \\
(2017)\end{array}$ & UK & $\begin{array}{l}\text { 1) To determine } \\
\text { the incidence of } \\
\text { functional stroke } \\
\text { mimics admitted } \\
\text { to a hyperacute } \\
\text { stroke unit. }\end{array}$ & $\begin{array}{l}\text { Retrospective } \\
\text { data analysis }\end{array}$ & $\begin{array}{l}\text { Functional } \\
\text { mimics }\end{array}$ & $\begin{array}{l}\text { Hyperacute } \\
\text { stroke unit }\end{array}$ & $\begin{array}{l}\text { Psychology, } \\
\text { counselling, } \\
\text { neurology, } \\
\text { gynaecological/ur } \\
\text { ology, general } \\
\text { medical/surgical, }\end{array}$ & $\begin{array}{l}18.4 \% \text { of } \\
\text { functional mimics } \\
\text { had dysarthria. } \\
14.3 \% \text { had } \\
\text { dysphasia. } \\
\text { Slurred speech }\end{array}$ & Not stated \\
\hline
\end{tabular}


Speech, language and swallowing impairments in FND: Data extraction chart

\begin{tabular}{|c|c|c|c|c|c|c|c|c|}
\hline $\begin{array}{l}\text { Author } \\
\text { and year }\end{array}$ & Country & Aim & $\begin{array}{l}\text { Research } \\
\text { Method }\end{array}$ & $\begin{array}{l}\text { Terminology } \\
\text { of diagnoses }\end{array}$ & Setting & $\begin{array}{l}\text { Treatment } \\
\text { approach }\end{array}$ & SLT symptoms & SLT involvement \\
\hline $\begin{array}{l}\text { Han et al. } \\
(2007)\end{array}$ & USA & $\begin{array}{l}\text { To present a case } \\
\text { report of a patient } \\
\text { with conversion } \\
\text { locked-in }\end{array}$ & Case report & $\begin{array}{l}\text { Conversion } \\
\text { disorder }\end{array}$ & Surgery & $\begin{array}{l}\text { Not stated- } \\
\text { spontaneously } \\
\text { resolved }\end{array}$ & Anarthric & Not stated \\
\hline
\end{tabular}


Speech, language and swallowing impairments in FND: Data extraction chart

\begin{tabular}{|c|c|c|c|c|c|c|c|c|}
\hline $\begin{array}{l}\text { Author } \\
\text { and year }\end{array}$ & Country & Aim & $\begin{array}{l}\text { Research } \\
\text { Method }\end{array}$ & $\begin{array}{l}\text { Terminology } \\
\text { of diagnoses }\end{array}$ & Setting & $\begin{array}{l}\text { Treatment } \\
\text { approach }\end{array}$ & SLT symptoms & SLT involvement \\
\hline & & syndrome & & & & & & \\
\hline $\begin{array}{l}\text { Haubenber } \\
\text { ger et al. } \\
(2004)\end{array}$ & Austria & $\begin{array}{l}\text { To present a case } \\
\text { report of a patient } \\
\text { with unusual } \\
\text { speech disorder }\end{array}$ & Case report & Psychogenic & Not stated & $\begin{array}{l}\text { Pharmacotherapy, } \\
\text { speech and } \\
\text { language therapy }\end{array}$ & $\begin{array}{l}\text { Dysarthrophonia, } \\
\text { difficulties } \\
\text { swallowing }\end{array}$ & $\begin{array}{l}\text { Voice and } \\
\text { breathing therapy }\end{array}$ \\
\hline $\begin{array}{l}\text { Healthcare } \\
\text { improvem } \\
\text { ent } \\
\text { Scotland } \\
(2012)\end{array}$ & UK & $\begin{array}{l}\text { To propose a } \\
\text { model of stepped } \\
\text { care for functional } \\
\text { neurological } \\
\text { symptoms }\end{array}$ & Report & $\begin{array}{l}\text { Functional } \\
\text { neurological } \\
\text { symptoms }\end{array}$ & $\begin{array}{l}\text { Whole } \\
\text { pathway - } \\
\text { from } \\
\text { primary to } \\
\text { tertiary care }\end{array}$ & $\begin{array}{l}\text { Psychology, } \\
\text { psychiatry, } \\
\text { physiotherapy, } \\
\text { occupational } \\
\text { therapy, speech } \\
\text { and language } \\
\text { therapy, } \\
\text { neurology, } \\
\text { rehabilitation } \\
\text { medicine, chronic } \\
\text { pain services }\end{array}$ & Not stated & $\begin{array}{l}\text { Stated in } \\
\text { recommendations } \\
\text { that SLTs should } \\
\text { be involved in } \\
\text { rehabilitation }\end{array}$ \\
\hline $\begin{array}{l}\text { Heruti et } \\
\text { al. }(2002)\end{array}$ & Israel & $\begin{array}{l}\text { To review recent } \\
\text { as well as } \\
\text { historically } \\
\text { important medical } \\
\text { literature of } \\
\text { patients with } \\
\text { conversion motor } \\
\text { paralysis }\end{array}$ & Review & $\begin{array}{l}\text { Conversion } \\
\text { motor } \\
\text { paralysis }\end{array}$ & N/A & $\begin{array}{l}\text { Psychology, } \\
\text { interdisciplinary } \\
\text { rehabilitation, } \\
\text { pharmacotherapy }\end{array}$ & $\begin{array}{l}\text { Speech disorders, } \\
\text { dysphagia, } \\
\text { dysphasia }\end{array}$ & Not stated \\
\hline $\begin{array}{l}\text { Hinson } \\
\text { and Haren } \\
(2006)\end{array}$ & USA & $\begin{array}{l}\text { To review the } \\
\text { epidemiology, } \\
\text { diagnosis and } \\
\text { current treatment } \\
\text { options for } \\
\text { psychogenic } \\
\text { movement } \\
\text { disorders }\end{array}$ & Review & $\begin{array}{l}\text { Psychogenic } \\
\text { movement } \\
\text { disorders }\end{array}$ & N/A & $\begin{array}{l}\text { Psychotherapy, } \\
\text { stress } \\
\text { management, } \\
\text { relaxation, } \\
\text { pharmacotherapy, } \\
\text { rehabilitation }\end{array}$ & $\begin{array}{l}\text { Speech listed as } \\
\text { possible symptom }\end{array}$ & Not stated \\
\hline Hinson et & USA & To develop and & Rating scale & Psychogenic & Movement & $\mathrm{N} / \mathrm{A}$ & 25/88 had speech & Not stated \\
\hline
\end{tabular}


Speech, language and swallowing impairments in FND: Data extraction chart

\begin{tabular}{|c|c|c|c|c|c|c|c|c|}
\hline $\begin{array}{l}\text { Author } \\
\text { and year }\end{array}$ & Country & Aim & $\begin{array}{l}\text { Research } \\
\text { Method }\end{array}$ & \begin{tabular}{|l|} 
Terminology \\
of diagnoses
\end{tabular} & Setting & $\begin{array}{l}\text { Treatment } \\
\text { approach }\end{array}$ & SLT symptoms & SLT involvement \\
\hline $\begin{array}{l}\text { Jokel and } \\
\text { Wolf } \\
\text { (2017) }\end{array}$ & Canada & $\begin{array}{l}\text { To provide } \\
\text { empirical and } \\
\text { clinical evidence }\end{array}$ & $\begin{array}{l}\text { Retrospective } \\
\text { review of } \\
\text { medical notes }\end{array}$ & $\begin{array}{l}\text { Conversion } \\
\text { disorder, } \\
\text { Ganser } \\
\end{array}$ & Not stated & $\begin{array}{l}\text { Treatment of } \\
\text { cases not } \\
\text { specified }\end{array}$ & $\begin{array}{l}2 / 10 \text { were } \\
\text { diagnosed with } \\
\text { conversion }\end{array}$ & $\begin{array}{l}\text { Evaluation using } \\
\text { speech and } \\
\text { language tests }\end{array}$ \\
\hline
\end{tabular}


Speech, language and swallowing impairments in FND: Data extraction chart

\begin{tabular}{|c|c|c|c|c|c|c|c|c|}
\hline $\begin{array}{l}\text { Author } \\
\text { and year }\end{array}$ & Country & Aim & $\begin{array}{l}\text { Research } \\
\text { Method }\end{array}$ & $\begin{array}{l}\text { Terminology } \\
\text { of diagnoses }\end{array}$ & Setting & $\begin{array}{l}\text { Treatment } \\
\text { approach }\end{array}$ & SLT symptoms & SLT involvement \\
\hline & & $\begin{array}{l}\text { that supports } \\
\text { multidisciplinary } \\
\text { assessment of } \\
\text { patients who } \\
\text { present with } \\
\text { speech, language } \\
\text { and cognitive } \\
\text { impairments that } \\
\text { do not seem to } \\
\text { have a clear } \\
\text { organic basis }\end{array}$ & & syndrome & & & $\begin{array}{l}\text { disorder with } \\
\text { general language } \\
\text { impairments } \\
(20 \%) \text { : } \\
\text { Dysgraphia, } \\
\text { alexia, naming } \\
\text { impairment, } \\
\text { repetition } \\
\text { impairment }\end{array}$ & \\
\hline $\begin{array}{l}\text { Karpman } \\
(1953)\end{array}$ & USA & $\begin{array}{l}\text { To describe a case } \\
\text { report of a patient } \\
\text { with psychogenic } \\
\text { dysphagia }\end{array}$ & Case report & $\begin{array}{l}\text { Psychogenic, } \\
\text { hysterical }\end{array}$ & Not stated & $\begin{array}{l}\text { Psychiatric } \\
\text { therapy }\end{array}$ & $\begin{array}{l}\text { Inability to } \\
\text { swallow solid } \\
\text { food }\end{array}$ & Not stated \\
\hline $\begin{array}{l}\text { Kim et al. } \\
(2018)\end{array}$ & Canada & $\begin{array}{l}\text { To describe a case } \\
\text { report of the use } \\
\text { of } \\
\text { electroconvulsive } \\
\text { therapy to treat } \\
\text { psychogenic } \\
\text { dysphagia }\end{array}$ & Case report & Psychogenic & Inpatient & $\begin{array}{l}\text { Electroconvulsive } \\
\text { therapy }\end{array}$ & Dysphagia & $\begin{array}{l}\text { For assessment of } \\
\text { swallowing }\end{array}$ \\
\hline $\begin{array}{l}\text { Koźmin- } \\
\text { Burzyńska } \\
\text { et al. } \\
(2015)\end{array}$ & Poland & $\begin{array}{l}\text { To present a case } \\
\text { report on } \\
\text { psychogenic } \\
\text { speech disorder }\end{array}$ & Case report & $\begin{array}{l}\text { Mixed } \\
\text { dissociative } \\
\text { (conversion) } \\
\text { disorder. } \\
\text { Psychogenic } \\
\text { speech } \\
\text { disorder }\end{array}$ & $\begin{array}{l}\text { Psychiatry } \\
\text { ward }\end{array}$ & $\begin{array}{l}\text { Psychodynamic } \\
\text { group } \\
\text { psychotherapy, } \\
\text { music therapy, art } \\
\text { therapy, } \\
\text { psychodrama, } \\
\text { relaxation }\end{array}$ & $\begin{array}{l}\text { Speech disorders: } \\
\text { cluttering, fast } \\
\text { rate of speech, } \\
\text { impaired } \\
\text { articulation }\end{array}$ & $\begin{array}{l}\text { Consultation for } \\
\text { diagnosis }\end{array}$ \\
\hline $\begin{array}{l}\text { Kranick et } \\
\text { al. }(2011)\end{array}$ & USA & $\begin{array}{l}\text { To assess the role } \\
\text { of previous life } \\
\text { stress using } \\
\text { validated }\end{array}$ & $\begin{array}{l}\text { Structured } \\
\text { clinical } \\
\text { interview, self- } \\
\text { report }\end{array}$ & $\begin{array}{l}\text { Psychogenic } \\
\text { movement } \\
\text { disorder }\end{array}$ & $\begin{array}{l}\text { Research } \\
\text { centre }\end{array}$ & Not stated & $\begin{array}{l}8 / 64 \text { had speech } \\
\text { symptoms } \\
(12.5 \%)\end{array}$ & Not stated \\
\hline
\end{tabular}


Speech, language and swallowing impairments in FND: Data extraction chart

\begin{tabular}{|c|c|c|c|c|c|c|c|c|}
\hline $\begin{array}{l}\text { Author } \\
\text { and year }\end{array}$ & Country & Aim & $\begin{array}{l}\text { Research } \\
\text { Method }\end{array}$ & $\begin{array}{l}\text { Terminology } \\
\text { of diagnoses }\end{array}$ & Setting & $\begin{array}{l}\text { Treatment } \\
\text { approach }\end{array}$ & SLT symptoms & SLT involvement \\
\hline & & $\begin{array}{l}\text { quantitative } \\
\text { measures in } \\
\text { patients with } \\
\text { psychogenic } \\
\text { movement } \\
\text { disorder }\end{array}$ & $\begin{array}{l}\text { psychiatric } \\
\text { measures }\end{array}$ & & & & & \\
\hline $\begin{array}{l}\text { Levy and } \\
\text { Jankovic } \\
(1983)\end{array}$ & USA & $\begin{array}{l}\text { To provide } \\
\text { positive } \\
\text { diagnostic criteria } \\
\text { for hysterical } \\
\text { symptoms }\end{array}$ & $\begin{array}{l}\text { Double- } \\
\text { dissociation } \\
\text { experiment }\end{array}$ & Hysteria & Test setting & $\begin{array}{l}\text { Patient was lost to } \\
\text { follow up }\end{array}$ & $\begin{array}{l}\text { Dysfluency, } \\
\text { dysarthria, } \\
\text { telegraphic } \\
\text { speech, } \\
\text { paraphasias, } \\
\text { circumlocution, } \\
\text { slow } \\
\text { comprehension }\end{array}$ & Not stated \\
\hline $\begin{array}{l}\text { Mendez } \\
(2018)\end{array}$ & USA & $\begin{array}{l}\text { To identify and } \\
\text { classify non- } \\
\text { neurogenic } \\
\text { language } \\
\text { disorders and } \\
\text { their } \\
\text { characteristics }\end{array}$ & $\begin{array}{l}\text { Literature } \\
\text { review }\end{array}$ & $\begin{array}{l}\text { Non- } \\
\text { neurogenic } \\
\text { language } \\
\text { disorders, } \\
\text { psychogenic }\end{array}$ & N/A & Not stated & $\begin{array}{l}\text { Description of } \\
\text { possible non- } \\
\text { neurogenic } \\
\text { language } \\
\text { disorders }\end{array}$ & Not stated \\
\hline $\begin{array}{l}\text { Mishra et } \\
\text { al. (2011) }\end{array}$ & $\begin{array}{l}\text { Switzerl } \\
\text { and }\end{array}$ & $\begin{array}{l}\text { To present a case } \\
\text { report of a patient } \\
\text { with left } \\
\text { hemiparesis, } \\
\text { mutism and } \\
\text { retrograde } \\
\text { amensia }\end{array}$ & Case report & $\begin{array}{l}\text { Dissociative } \\
\text { and } \\
\text { psychogenic }\end{array}$ & $\begin{array}{l}\text { Hospital } \\
\text { then } \\
\text { Neurobeha } \\
\text { vioural } \\
\text { Disorder } \\
\text { Clinic }\end{array}$ & Not stated & Mutism & Not stated \\
\hline $\begin{array}{l}\text { Moene et } \\
\text { al. }(2002)\end{array}$ & $\begin{array}{l}\text { Netherla } \\
\text { nds }\end{array}$ & $\begin{array}{l}\text { 1) To examine the } \\
\text { additional effects } \\
\text { of hypnosis aimed } \\
\text { at symptom } \\
\text { reduction in a }\end{array}$ & $\begin{array}{l}\text { Randomised } \\
\text { controlled trial }\end{array}$ & $\begin{array}{l}\text { Conversion } \\
\text { disorder }\end{array}$ & $\begin{array}{l}\text { Outpatient } \\
\text { or inpatient } \\
\text { treatment }\end{array}$ & $\begin{array}{l}\text { Nursing, group } \\
\text { therapy, creative } \\
\text { therapy, sports } \\
\text { therapy, } \\
\text { physiotherapy, }\end{array}$ & $\begin{array}{l}6 / 45 \text { had speech } \\
\text { disturbances } \\
(13.33 \%)\end{array}$ & Not stated \\
\hline
\end{tabular}


Speech, language and swallowing impairments in FND: Data extraction chart

\begin{tabular}{|c|c|c|c|c|c|c|c|c|}
\hline $\begin{array}{l}\text { Author } \\
\text { and year }\end{array}$ & Country & Aim & $\begin{array}{l}\text { Research } \\
\text { Method }\end{array}$ & $\begin{array}{l}\text { Terminology } \\
\text { of diagnoses }\end{array}$ & Setting & $\begin{array}{l}\text { Treatment } \\
\text { approach }\end{array}$ & SLT symptoms & SLT involvement \\
\hline & & $\begin{array}{l}\text { treatment } \\
\text { programme for } \\
\text { inpatients with a } \\
\text { persistent } \\
\text { conversion } \\
\text { disorder } \\
\text { 2) To assess } \\
\text { whether the level } \\
\text { of hypnotisability } \\
\text { was predictive of } \\
\text { treatment } \\
\text { outcome } \\
\text { 3) To explore the } \\
\text { efficacy of the } \\
\text { total clinical } \\
\text { treatment } \\
\text { programme }\end{array}$ & & & & hypnosis & & \\
\hline $\begin{array}{l}\text { Nakamura } \\
\text { et al. } \\
(2002)\end{array}$ & Japan & $\begin{array}{l}\text { To present two } \\
\text { case reports of } \\
\text { patients with } \\
\text { functional } \\
\text { retrograde } \\
\text { amnesia with } \\
\text { impairment of } \\
\text { object use }\end{array}$ & Case reports & Functional & Hospital & Not stated & $\begin{array}{l}\text { Deficits in } \\
\text { naming, oral } \\
\text { reading and } \\
\text { writing, word } \\
\text { finding } \\
\text { difficulties, } \\
\text { comprehension } \\
\text { difficulties at } \\
\text { single word level }\end{array}$ & Not stated \\
\hline $\begin{array}{l}\text { Nettleton } \\
\text { et al. } \\
(2005)\end{array}$ & UK & $\begin{array}{l}\text { To explore the } \\
\text { narratives of } \\
\text { patients with } \\
\text { medically } \\
\text { unexplained } \\
\text { illness }\end{array}$ & $\begin{array}{l}\text { In-depth } \\
\text { interviews }\end{array}$ & $\begin{array}{l}\text { Medically } \\
\text { unexplained } \\
\text { illness }\end{array}$ & $\begin{array}{l}\text { Neurology } \\
\text { clinic }\end{array}$ & Not stated & $\begin{array}{l}1 \text { participant had } \\
\text { swallowing } \\
\text { difficulties and } 1 \\
\text { had slurred } \\
\text { speech (not all } \\
\text { symptoms of all } \\
\text { participants were }\end{array}$ & Not stated \\
\hline
\end{tabular}


Speech, language and swallowing impairments in FND: Data extraction chart

\begin{tabular}{|c|c|c|c|c|c|c|c|c|}
\hline $\begin{array}{l}\text { Author } \\
\text { and year }\end{array}$ & Country & Aim & $\begin{array}{l}\text { Research } \\
\text { Method }\end{array}$ & $\begin{array}{l}\text { Terminology } \\
\text { of diagnoses }\end{array}$ & Setting & $\begin{array}{l}\text { Treatment } \\
\text { approach }\end{array}$ & SLT symptoms & SLT involvement \\
\hline & & & & & & & listed) & \\
\hline $\begin{array}{l}\text { Nielson et } \\
\text { al. (2017) }\end{array}$ & UK & $\begin{array}{l}\text { To develop a } \\
\text { simplified version } \\
\text { of the } \\
\text { Psychogenic } \\
\text { Movement } \\
\text { Disorders Rating } \\
\text { Scale and to } \\
\text { assess the } \\
\text { interrater } \\
\text { reliability, } \\
\text { concurrent } \\
\text { validity and } \\
\text { sensitivity }\end{array}$ & $\begin{array}{l}\text { Rating scale } \\
\text { development, } \\
\text { interrater } \\
\text { reliability, } \\
\text { concurrent } \\
\text { validity and } \\
\text { sensitivity } \\
\text { testing }\end{array}$ & $\begin{array}{l}\text { Functional } \\
\text { (psychogenic) } \\
\text { movement } \\
\text { disorder }\end{array}$ & Not stated & $\mathrm{N} / \mathrm{A}$ & $\begin{array}{l}\text { Speech disorder } \\
\text { included on rating } \\
\text { scale }\end{array}$ & Not stated \\
\hline $\begin{array}{l}\text { Park } \\
(2018)\end{array}$ & $\begin{array}{l}\text { South } \\
\text { Korea }\end{array}$ & $\begin{array}{l}\text { To describe } \\
\text { incidence and } \\
\text { clinical and } \\
\text { phenomenological } \\
\text { characteristics of } \\
\text { functional } \\
\text { movement } \\
\text { disorder patients }\end{array}$ & $\begin{array}{l}\text { Retrospective } \\
\text { analysis }\end{array}$ & $\begin{array}{l}\text { Functional } \\
\text { movement } \\
\text { disorder }\end{array}$ & $\begin{array}{l}\text { Outpatient } \\
\text { neurology } \\
\text { clinic }\end{array}$ & Antidepressants & $\begin{array}{l}\text { Abnormal speech } \\
\text { or voice in } 10 / 31 \\
\text { patients }(32 \%) \\
\text { however also } \\
\text { states } 12 / 31 \\
(39 \%) \text { had } \\
\text { affected speech or } \\
\text { voice. Infantile } \\
\text { speech and } \\
\text { dysarthria listed } \\
\text { as symptoms } \\
\end{array}$ & Not stated \\
\hline $\begin{array}{l}\text { Power et } \\
\text { al. (2018) }\end{array}$ & Ireland & $\begin{array}{l}\text { To present a case } \\
\text { report of a patient } \\
\text { with conversion } \\
\text { disorder }\end{array}$ & Case report & $\begin{array}{l}\text { Conversion } \\
\text { disorder }\end{array}$ & $\begin{array}{l}\text { Memory } \\
\text { clinic }\end{array}$ & $\begin{array}{l}\text { Trauma-focussed } \\
\text { counselling }\end{array}$ & $\begin{array}{l}\text { Word finding } \\
\text { difficulties }\end{array}$ & Not stated \\
\hline $\begin{array}{l}\text { Rosebush } \\
\text { and } \\
\text { Mazurek } \\
(2011)\end{array}$ & Canada & $\begin{array}{l}\text { To review the } \\
\text { treatment of } \\
\text { conversion } \\
\text { disorder }\end{array}$ & $\begin{array}{l}\text { Review and } \\
\text { opinion piece }\end{array}$ & $\begin{array}{l}\text { Conversion } \\
\text { disorder }\end{array}$ & $\mathrm{N} / \mathrm{A}$ & $\begin{array}{l}\text { Psychotherapy, } \\
\text { hypnotherapy, } \\
\text { narcotherapy, } \\
\text { pharmacotherapy }\end{array}$ & \begin{tabular}{|l} 
Speech \\
disturbances \\
listed as possible \\
symptoms of
\end{tabular} & $\begin{array}{l}\text { Opinion statement } \\
\text { reports SLTs } \\
\text { should be } \\
\text { involved, when }\end{array}$ \\
\hline
\end{tabular}


Speech, language and swallowing impairments in FND: Data extraction chart

\begin{tabular}{|c|c|c|c|c|c|c|c|c|}
\hline $\begin{array}{l}\text { Author } \\
\text { and year }\end{array}$ & Country & Aim & $\begin{array}{l}\text { Research } \\
\text { Method }\end{array}$ & $\begin{array}{l}\text { Terminology } \\
\text { of diagnoses }\end{array}$ & Setting & $\begin{array}{l}\text { Treatment } \\
\text { approach }\end{array}$ & SLT symptoms & SLT involvement \\
\hline & & & & & & & $\begin{array}{l}\text { conversion } \\
\text { disorder }\end{array}$ & $\begin{array}{l}\text { appropriate for } \\
\text { rehabilitation }\end{array}$ \\
\hline $\begin{array}{l}\text { Sachar and } \\
\text { Stimson } \\
(2015)\end{array}$ & UK & $\begin{array}{l}\text { To describe a case } \\
\text { report of a patient } \\
\text { who presented } \\
\text { multiple times to } \\
\text { the emergency } \\
\text { department with } \\
\text { functional } \\
\text { dysphagia }\end{array}$ & Case report & $\begin{array}{l}\text { Functional } \\
\text { dysphagia, } \\
\text { somatoform } \\
\text { disorder }\end{array}$ & $\begin{array}{l}\text { Emergency } \\
\text { department }\end{array}$ & $\begin{array}{l}\text { Pharmacotherapy, } \\
\text { relaxation and } \\
\text { education therapy, } \\
\text { cognitive } \\
\text { behaviour therapy }\end{array}$ & Dysphagia & Not stated \\
\hline $\begin{array}{l}\text { Saifee } \text { et } \\
\text { al. (2012) }\end{array}$ & UK & $\begin{array}{l}\text { To evaluate the } \\
\text { long term efficacy } \\
\text { of a } \\
\text { multidisciplinary } \\
\text { inpatient } \\
\text { programme for } \\
\text { patients with } \\
\text { functional motor } \\
\text { symptoms and to } \\
\text { identify factors } \\
\text { associated with } \\
\text { good outcome }\end{array}$ & Questionnaires & $\begin{array}{l}\text { Functional } \\
\text { neurological } \\
\text { disorder }\end{array}$ & $\begin{array}{l}\text { Inpatient } \\
\text { programme }\end{array}$ & $\begin{array}{l}\text { Neurophysiothera } \\
\text { py, occupational } \\
\text { therapy, cognitive } \\
\text { behavioural } \\
\text { therapy, nursing, } \\
\text { neuropsychiatry, } \\
\text { neurology }\end{array}$ & $\begin{array}{l}\text { Difficulty } \\
\text { speaking/slurred } \\
\text { speech (over } \\
50 \% \text { ). Difficulty } \\
\text { swallowing (just } \\
\text { under } 20 \% \text { ) }\end{array}$ & Not stated \\
\hline $\begin{array}{l}\text { Schwartz } \\
\text { et al. } \\
(2001)\end{array}$ & USA & $\begin{array}{l}\text { To present } \\
\text { cultural and social } \\
\text { considerations in } \\
\text { a case study of } \\
\text { conversion } \\
\text { disorder }\end{array}$ & Case report & $\begin{array}{l}\text { Conversion } \\
\text { disorder }\end{array}$ & $\begin{array}{l}\text { Emergency } \\
\text { room then } \\
\text { inpatient } \\
\text { neurology } \\
\text { ward }\end{array}$ & $\begin{array}{l}\text { Psychiatric } \\
\text { interview, } \\
\text { psychotherapy, } \\
\text { inpatient } \\
\text { psychiatric } \\
\text { hospitalisation, } \\
\text { hypnosis, } \\
\text { pharmacotherapy }\end{array}$ & Dysarthria & Not stated \\
\hline $\begin{array}{l}\text { Shapiro et } \\
\text { al. (1997) }\end{array}$ & USA & $\begin{array}{l}\text { To discuss the } \\
\text { clinical features } \\
\text { and strategies for }\end{array}$ & $\begin{array}{l}\text { Prospective } \\
\text { data collection } \\
\text { from clinical }\end{array}$ & Psychogenic & $\begin{array}{l}\text { Department } \\
\text { of Otology } \\
\text { and }\end{array}$ & $\begin{array}{l}\text { Psychology, } \\
\text { relaxation, } \\
\text { hypnosis }\end{array}$ & Phagophobia & Not stated \\
\hline
\end{tabular}


Speech, language and swallowing impairments in FND: Data extraction chart

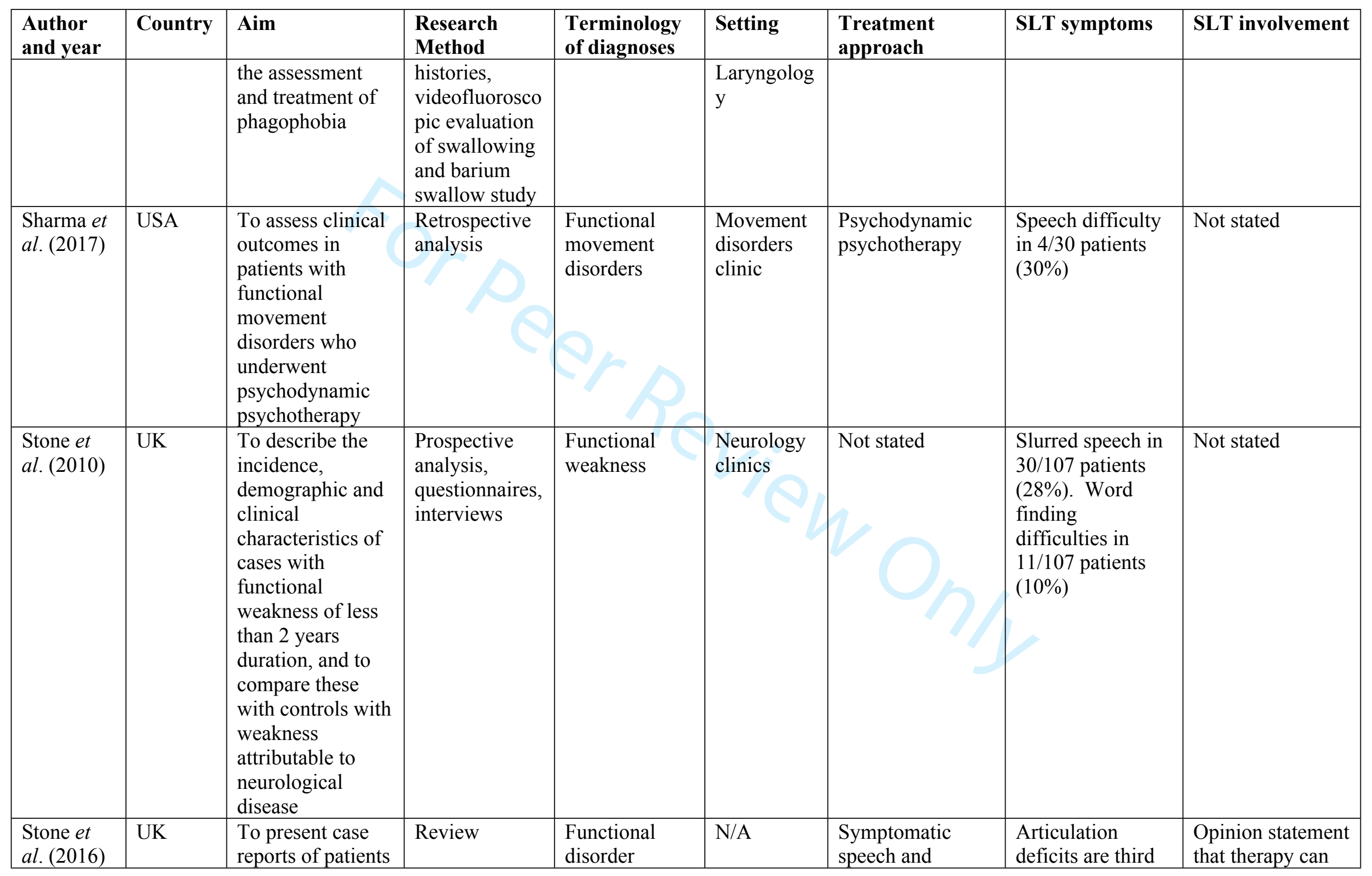


Speech, language and swallowing impairments in FND: Data extraction chart

\begin{tabular}{|c|c|c|c|c|c|c|c|c|}
\hline $\begin{array}{l}\text { Author } \\
\text { and year }\end{array}$ & Country & Aim & $\begin{array}{l}\text { Research } \\
\text { Method }\end{array}$ & $\begin{array}{l}\text { Terminology } \\
\text { of diagnoses }\end{array}$ & Setting & $\begin{array}{l}\text { Treatment } \\
\text { approach }\end{array}$ & SLT symptoms & SLT involvement \\
\hline & & $\begin{array}{l}\text { with functional } \\
\text { disorders }\end{array}$ & & & & language therapy & $\begin{array}{l}\text { commonest } \\
\text { functional speech } \\
\text { disorder (after } \\
\text { dysfluency and } \\
\text { dysphonia) }\end{array}$ & be effective \\
\hline $\begin{array}{l}\text { Stonningto } \\
\text { n et al. } \\
(2006)\end{array}$ & USA & $\begin{array}{l}\text { To present a case } \\
\text { report of a patient } \\
\text { with nonepileptic } \\
\text { seizures and } \\
\text { psychogenic } \\
\text { tremors }\end{array}$ & Case report & $\begin{array}{l}\text { Conversion } \\
\text { disorder }\end{array}$ & $\begin{array}{l}\text { Emergency } \\
\text { room then } \\
\text { epilepsy } \\
\text { monitoring } \\
\text { unit }\end{array}$ & $\begin{array}{l}\text { Psychotherapy, } \\
\text { pharmacotherapy, } \\
\text { hypnosis }\end{array}$ & $\begin{array}{l}\text { Monosyllabic } \\
\text { speech, voice } \\
\text { disturbance }\end{array}$ & Not stated \\
\hline $\begin{array}{l}\text { Suntrup et } \\
\text { al. (2014) }\end{array}$ & Germany & $\begin{array}{l}\text { To investigate } \\
\text { cortical swallow- } \\
\text { related activation } \\
\text { in patients } \\
\text { diagnosed with } \\
\text { functional } \\
\text { dysphagia using } \\
\text { magnetoencephal } \\
\text { ograph }\end{array}$ & $\begin{array}{l}\text { Case control } \\
\text { study }\end{array}$ & Functional & Test setting & Not stated & Dysphagia & Not stated \\
\hline $\begin{array}{l}\text { Teodoro et } \\
\text { al. (2018) }\end{array}$ & UK & $\begin{array}{l}\text { To define the key } \\
\text { neuropsychologic } \\
\text { al characteristics } \\
\text { of fibromyalgia, } \\
\text { chronic fatigue } \\
\text { syndrome and } \\
\text { functional } \\
\text { neurological } \\
\text { disorder }\end{array}$ & $\begin{array}{l}\text { Systematic } \\
\text { review }\end{array}$ & $\begin{array}{l}\text { Functional } \\
\text { cognitive } \\
\text { disorder }\end{array}$ & $\mathrm{N} / \mathrm{A}$ & Not stated & $\begin{array}{l}\text { Naming and/or } \\
\text { fluency } \\
\text { abnormalities } \\
\text { found in patients } \\
\text { with non-epileptic } \\
\text { attacks }\end{array}$ & Not stated \\
\hline $\begin{array}{l}\text { Thomas et } \\
\text { al. (2006) }\end{array}$ & USA & $\begin{array}{l}\text { To assess the } \\
\text { relationship } \\
\text { between } \\
\text { underlying }\end{array}$ & $\begin{array}{l}\text { Telephone } \\
\text { survey, } \\
\text { retrospective } \\
\text { analysis }\end{array}$ & $\begin{array}{l}\text { Psychogenic } \\
\text { movement } \\
\text { disorder }\end{array}$ & $\begin{array}{l}\text { Movement } \\
\text { disorders } \\
\text { clinic }\end{array}$ & $\begin{array}{l}\text { Pharmacotherapy, } \\
\text { placebo, } \\
\text { biofeedback, } \\
\text { relaxation, }\end{array}$ & $\begin{array}{l}\text { Dysarthria, word } \\
\text { finding } \\
\text { difficulties, } \\
\text { mutism. Specific }\end{array}$ & Not stated \\
\hline
\end{tabular}


Speech, language and swallowing impairments in FND: Data extraction chart

\begin{tabular}{|c|c|c|c|c|c|c|c|c|}
\hline $\begin{array}{l}\text { Author } \\
\text { and year }\end{array}$ & Country & Aim & $\begin{array}{l}\text { Research } \\
\text { Method }\end{array}$ & $\begin{array}{l}\text { Terminology } \\
\text { of diagnoses }\end{array}$ & Setting & $\begin{array}{l}\text { Treatment } \\
\text { approach }\end{array}$ & SLT symptoms & SLT involvement \\
\hline & & $\begin{array}{l}\text { psychiatric factors } \\
\text { and long-term } \\
\text { prognosis of } \\
\text { psychogenic } \\
\text { movement } \\
\text { disorders }\end{array}$ & & & & $\begin{array}{l}\text { psychology, } \\
\text { psychiatry, } \\
\text { physiotherapy }\end{array}$ & $\begin{array}{l}\text { number of } \\
\text { patients with } \\
\text { these symptoms } \\
\text { not stated }\end{array}$ & \\
\hline $\begin{array}{l}\text { Vaiman et } \\
\text { al. (2008) }\end{array}$ & Israel & $\begin{array}{l}\text { To investigate the } \\
\text { usefulness of } \\
\text { surface } \\
\text { electromyography } \\
\text { of psychogenic } \\
\text { swallowing } \\
\text { disorders }\end{array}$ & $\begin{array}{l}\text { Case control } \\
\text { study }\end{array}$ & Psychogenic & Test setting & Not stated & Dysphagia & Not stated \\
\hline $\begin{array}{l}\text { Witte and } \\
\text { Mariën } \\
(2015)\end{array}$ & Belgium & $\begin{array}{l}\text { To present a case } \\
\text { report of a patient } \\
\text { with non-organic } \\
\text { language deficits } \\
\text { following awake } \\
\text { brain surgery }\end{array}$ & Case report & $\begin{array}{l}\text { Psychogenic } \\
\text { and non- } \\
\text { organic } \\
\text { language } \\
\text { disorder }\end{array}$ & Surgery & Not stated & $\begin{array}{l}\text { Receptive } \\
\text { dysphasia, anomia }\end{array}$ & Not stated \\
\hline $\begin{array}{l}\text { Yazici et } \\
\text { al. }(2004)\end{array}$ & Turkey & $\begin{array}{l}\text { To present the } \\
\text { somatosensory } \\
\text { evoked potential } \\
\text { responses in two } \\
\text { patients with } \\
\text { conversion } \\
\text { disorder }\end{array}$ & Case reports & $\begin{array}{l}\text { Conversion } \\
\text { disorder }\end{array}$ & $\begin{array}{l}\text { Hospital } \\
\text { and } \\
\text { inpatient } \\
\text { psychiatric } \\
\text { ward }\end{array}$ & $\begin{array}{l}\text { 1) Psychotherapy } \\
\text { and } \\
\text { pharmacotherapy } \\
\text { 2) } \\
\text { Electroconvulsive } \\
\text { therapy }\end{array}$ & $\begin{array}{l}\text { 1) Slurred speech } \\
\text { 2) Speech } \\
\text { difficulties }\end{array}$ & Not stated \\
\hline
\end{tabular}

N/A=not applicable; UK=United Kingdom; USA=United States of America

\section{References}

Afolabi, K., Ali, S., Gahtan, V., Gorji, R., Li, F. and Nussmeier, N., 2016, Postoperative conversion disorder. Journal of Clinical Anesthesia. 30, 
$21-23$.

Akyüz, F., Gökalp, P. G., Erdİman, S., Oflaz, S. and Karşidağ, Ç., 2017, Conversion disorder comorbidity and childhood trauma. Archives of Neuropsychiatry, 54, 15-20.

Al-Samarrai, S. H., Kramer, E. and Newmark, T., 1992, Palilalia as a conversion disorder. Psychosomatics, 42(3), $277-279$.

Andrade, C., Bhakta, S. G. and Singh, N. M., 2009, Systematic enhancement of functioning as a therapeutic technique in conversion disorder. Indian Journal of Psychiatry, 51, 134-136.

Artto, V., Putaala, J., Strbian, D., Meretoja, A., Piironen, K., Liebkind, R., Silvennoinen, H., Atula, S. and Happola, O., 2012, Stroke mimics and intravenous thrombolysis. Annals of Emergency Medicine, 59(1), 27-32.

Babin, P. and Gross, P., 2002, Traumatic brain injury when symptoms don’t add up: Conversion and malingering in the rehabilitation setting. Journal of Rehabilitation, 68(2), 4-13.

Baizabal-Carvallo, J.F. and Jankovic, J., 2015, Speech and voice disorders in patients with psychogenic movement disorders. Journal of Neurology, 262(11),.2420-2424.

Baizabal-Carvallo, J. F. and Jankovic, J., 2017, Functional (psychogenic) stereotypies. Journal of Neurology, 264, $1482-1487$.

Barofsky, I. and Fontaine, K., 1998, Do psychogenic dysphagia patients have an eating disorder? Dysphagia, 13, $24-27$.

Bryant, R. A. and Das, P., 2012, The neural circuitry of conversion disorder and its recovery. Journal of Abnormal Psychology, 121(1), 289-296.

Cantello, R., Boccagni, C., Comi, C., Civardi, C. and Monaco, F., 2001, Diagnosis of psychogenic paralysis: The role of motor evoked potentials. Journal of Neurology, 248, 889-897. 
Carter, A. B., 1967, The functional overlay. The Lancet, 2, 1196-1200.

Chen, Y., Bogosavljevic, V., Leys, D., Jovanovic, D., Beslac-Bumbasirevic, L., and Lucas, C., 2011, Intravenous thrombolytic therapy in patients with stroke mimics: Baseline characteristics and safety profile. European Journal of Neurology, 18(10),1246-1250.

Chung, D., Wettroth, C., Hallett, M. and Maurer, C., 2018, Functional speech and voice disorders: Case series and literature review. Movement Disorders Clinical Practice, 5(3), 312-316.

Cubo, E., Hinson, V., Goetz, C., Ruiz, P., Yebenes, J., Marti, M., Oroz, M., Linazasoro, G., Chacón, J., Váquez, A., Lópex del Val, J., Leurgans, S. and Wuu, J., 2005, Transcultural comparison of psychogenic movement disorders. Movement Disorders, 20(10), $1343-1345$.

Czarnecki, K., Thompson, J., Seime, R., Geda, Y., Duffy, J. and Ahlskog, J., 2012, Functional movement disorders: Successful treatment with a physical therapy rehabilitation protocol. Parkinsonism and Related Disorders, 18(3), 247-251.

De Letter, M., Van Borsel, J., Penen, K., Hemelsoet, D., Vervaet, V., Meurs, A. and Santens, P., 2012, Non-organic language disorders: Three case reports. Aphasiology, 26(7), 867-879.

Dwyer, J. and Reid, S., 2004, Ganser's syndrome. Lancet, 364, 471-473.

Epstein, S. A., Maurer, C. W., LaFaver, K., Ameli, R., Sinclair, S. and Hallett, M., 2016, Insights into chronic functional movement disorders: The value of qualitative psychiatric interviews. Psychosomatics, 57, 566-575.

Ertan, S., Uluduz, D., Özekmekçi, S., Kiziltan, G., Ertna, T., Yalçinkaya, C. and Özkara, Ç., 2009, Clinical characteristics of 49 patients with psychogenic movement disorders in a tertiary clinic in Turkey. Movement Disorders, 24(5), 759-782.

Factor, S., Podskalny, G. and Molho, E., 1995, Psyschogenic movement disorders: Frequency, clinical profile and characteristics. Journal of 
Neurology, Neurosurgery and Psychiatry, 59, 406-412.

Fasano, A., Valadas, A., Bhatia, K., Prashanth, L., Lang, A., Munhoz, R., Morgante, F., Tarsy, D., Duker, A., Girlanda, P., Bentivoglio, A. and Espay, A., 2012, Psychogenic facial movement disorders: clinical features and associated conditions. Movement Disorders, 27(12), 15441551.

Ganos, C., Aguirregomozcorta, M., Batla, A., Stamelou, M., Schwingenschuh, P., Münchau, A., Edwards, M. J. and Bhatia, K. P., 2014, Psychogenic paroxysmal movement disorders - Clinical features and diagnostic clues. Parkinsonism and Related Disorders, 20, $41-46$.

Gargalas, S., Weeks, R., Khan-Bourne, N., Shotbolt, P., Simblett, S., Ashraf, L., Doyle, C., Bancroft, V. and David, A., 2017, Incidence and outcome of functional stroke mimics admitted to a hyperacute stroke unit. Journal of Neurology Neurosurgery and Psychiatry, 0, 1-5.

Gill, D. J. and Damann, K. M., 2015, Language dysfunction. Continuum, 21(3), 627-645.

Guillan, M., Alonso-Canovas, A., Gonzalez-Valcarcel, J., Barragan, N., Caldentey, J., Hernandez-Medrano, I., DeFilipe-Mimbrera, A., SanchezGonzalez, V., Terecoasa, E., Alonso de Leciñana, M. and Masjuan, J., 2012, Stroke mimics treated with thrombolysis: Further evidence on safety and distinctive clinical features. Cerebrovascular Diseases, 34(2), 115-120.

Han, D., Connelly, N. R., Weintraub, A., Kanev, P. and Solis, E., 2007, Conversion locked-in syndrome after implantation of a spinal cord stimulator. Anesthesia and Analgesia, 104(1), 163-165.

Haubenberger, D., Vigl, M., Busslinger, I., Denk, D., Fertl, E. and Auff, E., 2004, Psychogenic or non-psychogenic dysarthrophonia? Movement Disorders, 19(Supplement 9), S416.

Healthcare Improvement Scotland, 2012, Stepped Care for Functional Neurological Symptoms. [online] Available: http://www.healthcareimprovementscotland.org/our_work/long_term_conditions/neurological_health_services/neurological_symptoms_rep 
ort.aspx. [accessed 30 July 2018 ].

Heruti, R. J., Levy, A., Adunski, A. and Ohry, A., 2002, Conversion motor paralysis disorder: overview and rehabilitation model. Spinal Cord, 40(7), 327-334.

Hinson, V.K., Cubo, E., Comella, C., Goetz, C. and Leurgans, S., 2005, Rating scale for psychogenic movement disorders: Scale development and clinimetric testing. Movement Disorders, 20(12), 1592-1597.

Hinson, V. K. and Haren, W. B., 2006, Psychogenic movement disorders. Lancet Neurology, 5, 695-700.

Jacob, A. E., Kaelin, D. L., Roach, A. R., Ziegler, C. H. and LaFaver, K., 2018, Motor retraining (MoRe) for functional movement disorders: Outcomes from a 1-week multidisciplinary rehabilitation program. Physical Medicine and Rehabilitation, 1-9.

Jokel, R. and Conn, D., 1999, Case study: Mirror reading, writing and backward speech in a woman with a head injury: a case of conversion disorder. Aphasiology, 13(6), 495-509.

Jokel, R. and Wolf, U., 2017, When a duck is not a duck: Non-organic bases for aphasia and dementia. Aphasiology, 31(1), $100-121$.

Karpman, B., 1953, Psychogenic (hysterical) dysphagia. American Journal of Orthopsychiatry, 23(3), 472-500.

Kim, T. S. Y., Munshi, T. and Hussain, M., 2018, Resolution of severe psychogenic dysphagia with ECT in an elderly patient. International Psychogeriatrics, 30(7), 1081-1083.

Koźmin-Burzyńska, A., Bratek, A., Zawada, K., Krysta, K. and Krupka-Matuszczyk, I., 2015, Psychogenic speech disorder- A case report. Psychiatria Danubina, 27(Supplement 1), S411-S414.

Kranick, S., Ekanayake, V., Martinez, V., Arneli, R., Hallett, M. and Voon, V., 2011, Psychopathology and psychogenic movement disorders. 
Movement Disorders, 26(10), 1844-1850.

Levy, R. S. and Jankovic, J., 1983, Placebo-induced conversion reaction: A neurobehavioral and EEG study of hysterical aphasia, seizure, and coma. Journal of Abnormal Psychology, 92(2), 243-249.

Mendez, M. F., 2018, Non-neurogenic language disorders: A preliminary classification. Psychosomatics, 59, 28-35.

Mishra, N. K., Russmann, H., Granziera, C., Maeder, P. and Annoni, J.-M., 2011, Mutism and amnesia following high-voltage electrical injury: Psychogenic symptomatology triggered by organic dysfunction? European Neurology, 66(4), 229-234.

Moene, F.C., Spinhoven, P., Hoogduin, K. and van Dyck, R., 2002, A randomised controlled clinical trial on the additional effect of hypnosis in a comprehensive treatment programme for in-patients with conversion disorder of the motor type. Psychotherapy and Psychosomatics, 71(2), 66-76.

Nakamura, H., Kunori, Y., Mori, K., Nakaaki, S., Yoshida, S., Hamanaka, T., 2002, Two cases of functional focal retrograde amnesia with impairment of object use., Cortex, 38, 613-622.

Nettleton, S., Watt, I., O’Malley, L. and Duffey, P., 2005, Understanding the narratives of people who live with medically unexplained illness', Patient Education and Counseling, 56(2), 205-210.

Nielsen, G., Ricciardi, L., Meppelink, A., Holt, K., Teodoro, T., Edwards, M., 2017, A simplified version of the Psychogenic Movement Disorders Rating Scale: The Simplified Functional Movement Disorders Rating Scale (S-FMDRS). Movement Disorders Clinical Practice, 38(1), 42-49.

Park, J. E., 2018, Clinical characteristics of functional movement disorders: A clinic-based study. Tremor and Other Hyperkinetic Movements, 8 , $1-5$. 
Power, C., Hannigan, O., Coen, R., Bruce, I., Gibb, M., McCarthy, M., Robinson, D. and Lawlor, B. A., 2018, Prosopagnosia as a type of conversion disorder. Case Reports in Psychiatry, 2018, 1-5.

Rosebush, P.I. and Mazurek, M.F., 2011, Treatment of conversion disorder in the 21st century: Have we moved beyond the couch? Current Treatment Options in Neurology, 13(3), 255-266.

Sachar, A. and Stimson, E., 2015, The choking woman. London Journal of Primary Care, 7(2), 25-30.

Saifee, T.A., Kassavetis, P., Pareés, I., Kojovic, M., Fisher, L., Morton, L., Foong, J., Price, G., Joyce, E. and Edwards, M.., 2012, Inpatient treatment of functional motor symptoms: A long-term follow-up study. Journal of Neurology, 259(9), 1958-1963.

Schwartz, A. C., Calhoun, A. W., Eschback, C. L. and Seelig, B. J., 2001, Treatment of conversion disorder in an African American Christian woman: Cultural and social considerations. The American Journal of Psychiatry, 158(9), 1385-1391.

Shapiro, J., Franko, D. and Gagne, A., 1997, Phagophobia: A form of psychogenic dysphagia. A new entity. The Annals of Otology, Rhinology \& Laryngology, 106(4), 286-290.

Sharma, V. D., Jones, R. and Factor, S. A., 2017, Psychodynamic psychotherapy for functional (psychogenic) movement isorders. Journal of Movement Disorders, 10(1), 40-44.

Stone, J., Warlow, C. and Sharpe, M., 2010, The symptom of functional weakness: A controlled study of 107 patients. Brain, $133,1537-1551$.

Stone, J., Hoeritzauer, I., Gelauff, J., Lehn, A., Gardiner, P., van Fils, A. and Carson, A., 2016, Functional disorders in neurology: Case studies. Neurologic Clinics, 34(3), 667-681.

Stonnington, C. M., Barry, J. J. and Fisher, R. S., 2006, Conversion disorder. The American Journal of Psychiatry, 163(9), $1510-1517$. 
Suntrup, S., Teismann, I., Wollbrink, A., Warnecke, T., Winkels, M., Pantev, C. and Dziewas, R., 2014, Altered cortical swallowing processing in patients with functional dysphagia: A preliminary study. PLOS ONE, 9(2), 1-7.

Teodoro, T., Edwards, M. J. and Isaacs, J. D., 2018, A unifying theory for cognitive abnormalities in functional neurological disorders, fibromyalgia and chronic fatigue syndrome: Systematic review. Cognitive Neurology, 0, 1-12.

Thomas, M., Dat Vuong, K. and Jankovic, J., 2006, Long-term prognosis of patients with psychogenic movement disorders. Parkinsonism and Related Disorders, 12, 382-387.

Vaiman, M., Shoval, G. and Gavriel, H., 2008, The electrodiagnostic examination of psychogenic swallowing disorders', European Archives of Oto-Rhino-Laryngology, 265, 663-668.

De Witte, E. and Mariën, P., 2015, Non-organic language deficits following awake brain surgery: A case report', Clinical Neurology and Neurosurgery, 130, 11-13.

Yazici, K. M., Demirci, M., Demir, B. and Ertugrul, A., 2004, Abnormal somatosensory evoked potentials in two patients with conversion disorder. Psychiatry and Clinical Neurosciences, 58(2), 222-225. 
Speech, language and swallowing impairments in FND: Distribution of articles by year of publication and country of origin (UK=United Kingdom, USA= United States of America)

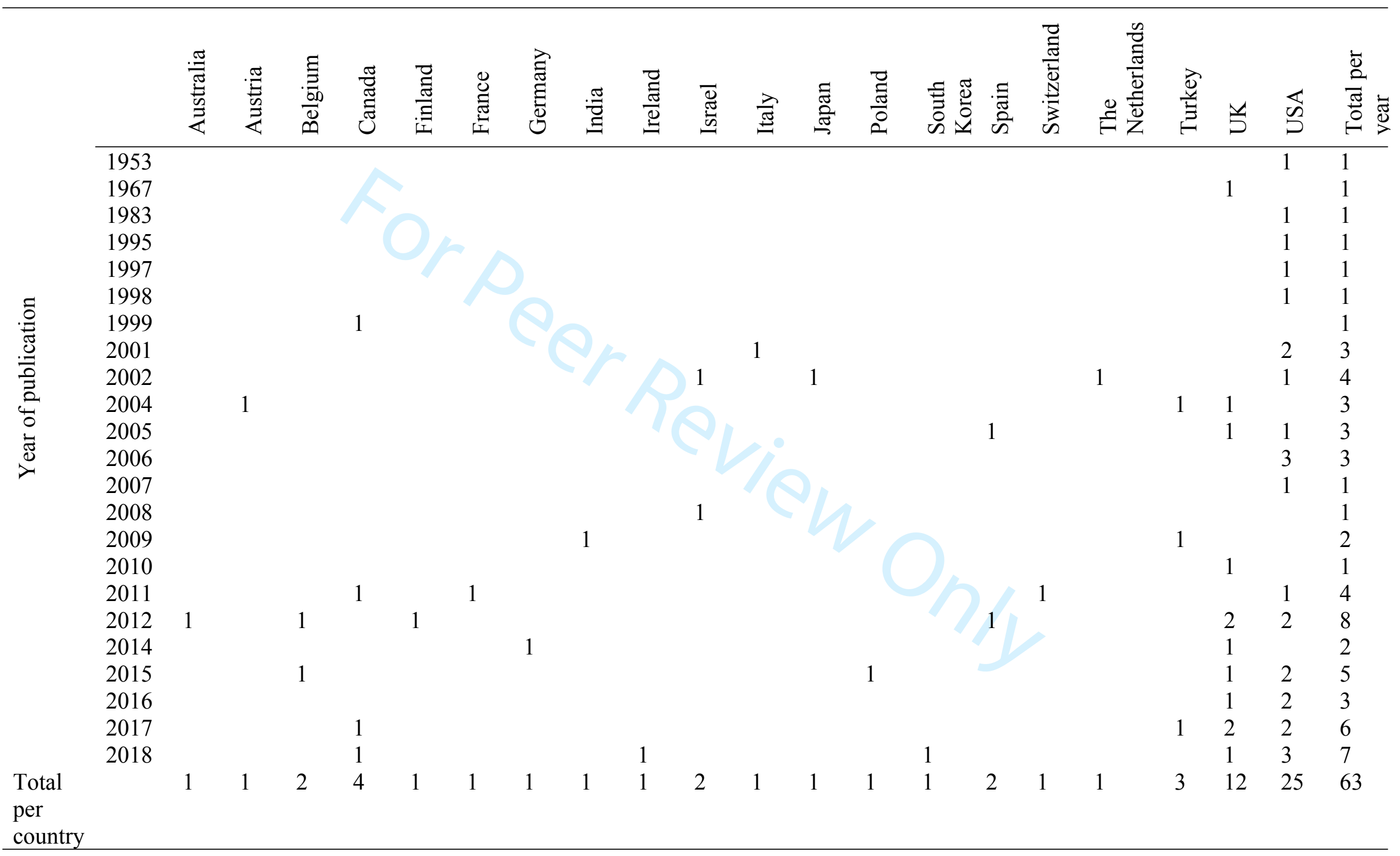

